Historic, Archive Document

Do not assume content reflects current scientific knowledge, policies, or practices. 


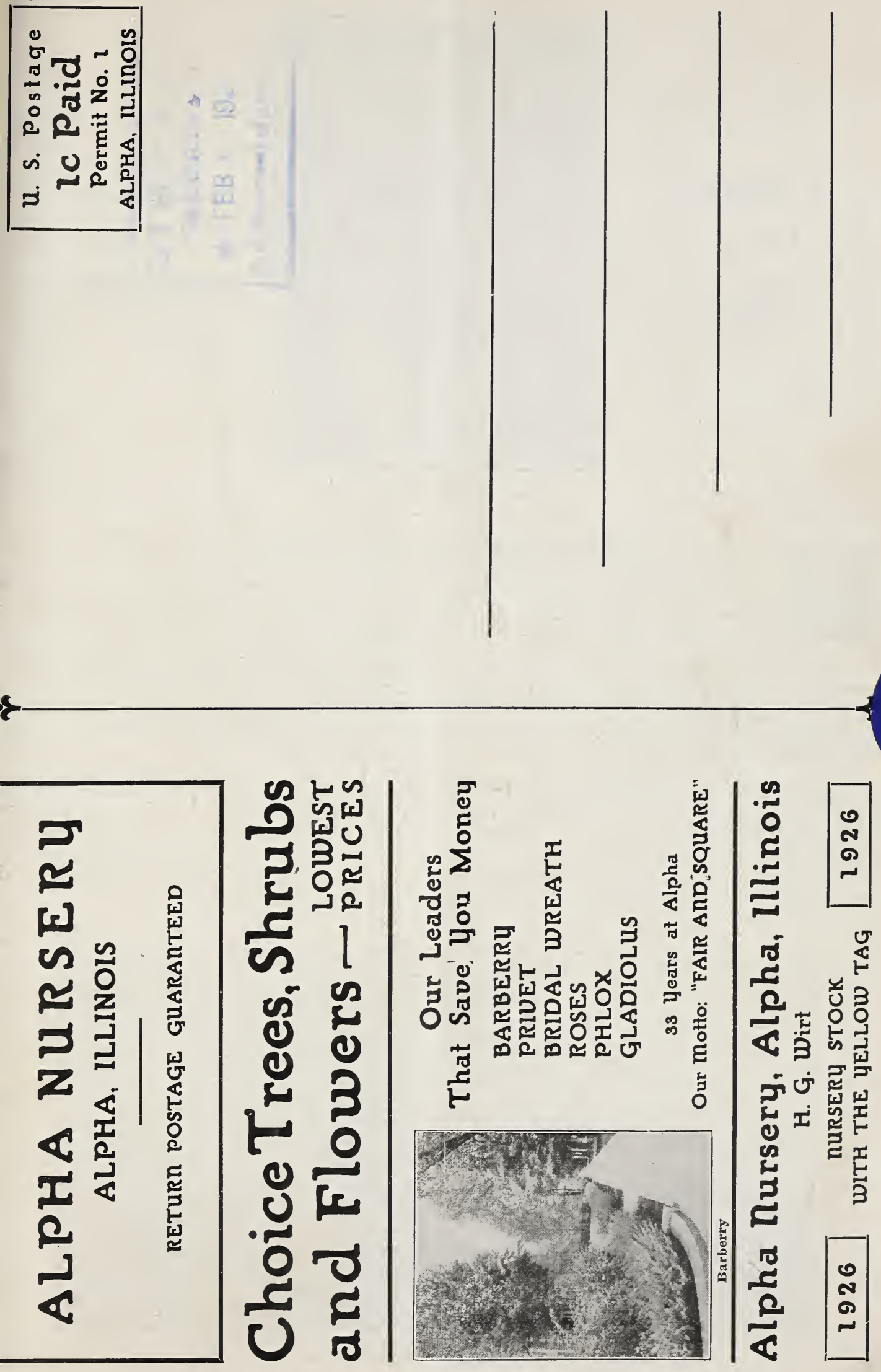


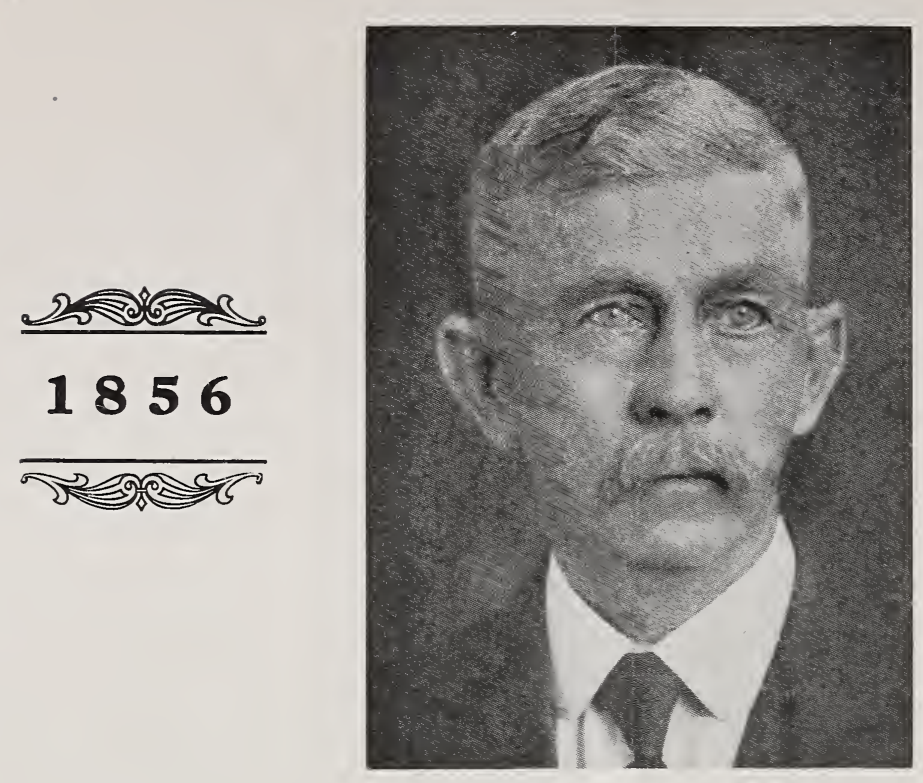

Originator of the Alpha Nursery

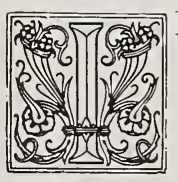

1892 the late Mr. George G. Wirt came to Alpha, Illinois, from Portland, Oregon, where he owned one-half interest in a large wholesale Nursery, having sold his half interest there he came to his native state, as Mr. Wirt was born in Keithsburg, 71 years ago. He started when just a boy in growing small fruits, later he budded and grafted fruit trees which he sold locally

In 1892 Mr. Wirt purchased a piece of land at Alpha, Illinois, and started the Alpha Nursery, which business has been steadily increasing, as Mr. IVirt's great aim was to have every plant TRUE TO NAME (although mistakes sometimes happened he was always ready to corect them). To treat everyone fair and square, give good service, and big values by giving the lowest prices on good reliable stock.

The ALPHA NURSERY will always try to uphold the great aim of Mr. Wirt, Sr., by improving the service, improving the trees, shrubs and plants, growing them better and selling them lower and still maintain the best of quality. If you receive anything from us which you think is not right, tell us about it, as we are the only one that will make it right. We will do everything we can to have every customer satisfied, and treated fair and square. We like to be treated that way, so do you.

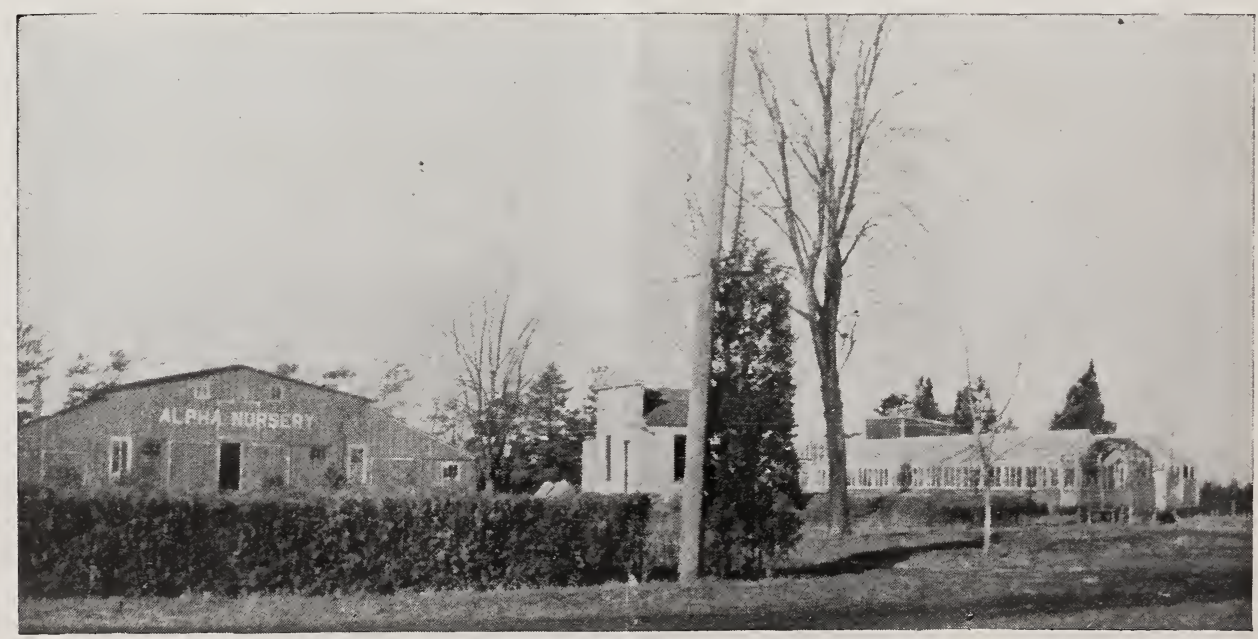

Office, Greenhouse and Packing Sheds. 


\section{Where We Are}

How to reach our NURSERY by Auto. We are only 18 miles from Galesburg; 32 from Rock Island, or Moline; 20 from Aledo or Galva.

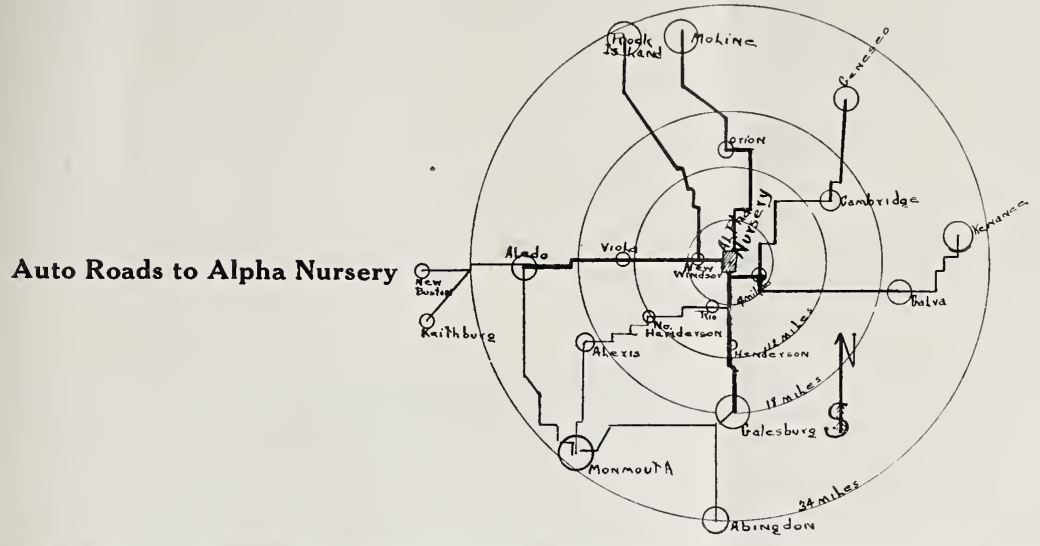

COME AND GET 'EM

Drive up to the Nursery, load your stock in the car and be home in a few hours. Hundreds do this every year. April and May in the spring. October and November in the fall. The roads are usually good.

\section{GENERAL INFORMATION}

\section{PRICES HEREIN CANCEL ALL PREVIOUS PRICE LISTS}

LOCATION-We are located midway between Galesburg and Rock Island, and about midway between Galva and Burlington, on the C. B. \& Q. R. R., therefore can ship in any direction.

Our grounds are located opposite the depot, our office and packing sheds adjoining the tracks, which makes delivery very convenient and without delay.

SHIPPING-We have extra good shipping facilities. Four local freights and eight express trains each day. We will ship all small packages by Express or Parcel Post, and recommend the larger packages to be sent by Express, even if the cost is a trifle more than freight, thus insuring immediate delivery.

PARCEL POST-The parcel post service is now improved so we can send packages up to $50 \mathrm{lbs}$. On distances up to 350 miles, parcel post is cheaper than express, but over this distance express is little the cheaper.

We have a parcel post department in which we list trees and plants in sizes that can go by parcel post. Kindly use this department when stock is to be shipped in this manner. DO NOT FORGET TO ADD POSTAGE.

Please do not ask us to send trees larger than we list in this department by parcel post, as the post office will not accept them, and therefore will cause a delay in getting your order started.

TERMS-Cash or satisfactory references from unknown parties before shipment.

PACKING-These prices are for well packed stock, and delivered to the rail road station at ALPHA.

MISTAKES cheerfully corrected, but no claims allowed unless made within seven days after shipment is received.

GUARANTEE-We guarantee all Nursery stock to be true to name, and should any prove not, we will return the amount paid for such stock, or replace with stock that is true, but we are not liable for damages other than herein named.

REPLACING-We do so at one-half the original price on fruit trees and shrubs, providing a list of the varieties that did not grow is sent to us within four months after the stock is received. Otherwise we do not.

RATES-Six at dozen, 50 at 100 rates, unless otherwise stated. This applies to trees, plants, etc., of any one class having a common price.

SHIPPING TIME-Spring shipments start about the first week in April and continue until last of May. Fall shipment starts about the middle of October and continues until freezing weather.

SUBSTITUTION-We desire to follow the customer's wishes and will not substitute unless we are out of the varieties ordered, and then to our best judgment, unless advised otherwise.

DISEASE-Our stock and premises are inspected each year by a State inspector, and a certificate issued, that such are apparently free from all dangerous insects and diseases. A certificate of inspection accompanies each shipment. 


\section{PRICES HEREIN CANCEL ALL PREVIOUS LISTS}

We Pay The Transportation Charges on all orders amounting to $\$ 20.00$ or over, if east of Colorado, except on large shade trees. We will use our judgment how to send the shipments.

\section{APPLES}

$\begin{array}{llrrr} & \text { Each } & \text { Per } 5 & \text { Per } 10 & \text { Per } 100 \\ \text { 1st size, } 4 \text { to } 6 \text { ft. trees, 2 year old } & \mathbf{5 0 c} & \mathbf{\$ 2 . 3 5} & \mathbf{\$ 4 . 5 0} & \mathbf{\$ 4 2 . 5 0}\end{array}$

(By Express Only).

\section{SUMMER VARIETIES}

Benonia-Medium, roundish, pale yellow shaded with crimson; juicy, tender, sub-acid; August.

\section{Early Harvest - Medium, to large, round-} flesh white, good quality. July.

Astrachan Red-Large, roundish, nearly covered with crimson; juicy, sub-acid; tree strong, spreading grower. August.

Red June-Medium, oblong, hardy and productive; deep red color; flesh white, tender, rich and sub-acid. August.

\section{Yellow Transparent- Medium, yel-} quality, productive, early bearer. July.

Liveland Raspberry-A very early variety of fine quality, good size, white striped and shaded with crimson; a good healthy grower, very hardy.

\section{AUTUMN VARIETIES}

Duchess of Oldenberg-Large size, roundish, streaked with red and yellow, flesh white, juicy, acid. September.

\section{Famuese (Snow) — M edium, deep} snowy white, tender. Tree slow crooked grower. October and November.

Golden Sweet-Fruit large, pale yellow; flesh tender, sweet and rich; hardy and a good grower. August and September.

Wealthy - Large, roundish, smooth, nearly covered with dark red; flesh white, fine, juicy, sub-acid quality very good; good grower and productive. October.

\section{WINTER VARIETIES}

Baldwin-Medium size, red, flesh yellow, subacid; tree a good grower, but a little tender here. December.

Delicious_ Fruit large, nearly covered with grained, crisp and melting, juicy, with a delightful aroma; of very highest quality. December to February.

Domine-Medium size, flat, greenish yellow with red stripes; flesh white, tender and juicy. Tree hardy, vigorous and productive. Early bearer. January.
Grimes Golden - Medium golden yellow, with white dots, crisp, tender and juicy, excellent; tree vigorous, hardy and productive. November to January.

Gano-Good size, smooth and very attractive; deep red, resembles Ben Davis, but is an improvement on that variety, being handsomer and better colored. December to March.

Golden Russet-Medium size; flesh greenish white, good quality; tree a good grower and hardy. January.

Golden Winesap-New Variety, one of the most promising offered in the past twenty years. Color yellow, with a slight red blush, juicy flavor of the Jonathan, and the meatiness of the old Winesap, good size, and good keeper, abundant bearer. December to March.

Jonathan-Medium, nearly covered with brilliant stripes of lively red; very showy, juicy, excellent; trees spreading and slender; bears early. November to February.

Mammoth Black Twig-Large, deep red, subacid; early and abundant bearer; keeps well; tree a strong grower; resembles IVinesap, but is superior in many ways, and fully one-third larger. January to April.

Northwestern Greening-Large, smooth, greenish yellow; flesh fine grained, firm; extremely hardy and a strong, handsome grower. December to April.

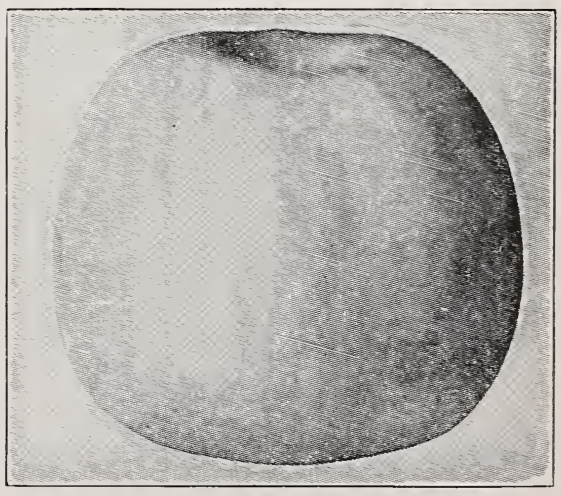

Grimes Golden 
Paradise Sweet-Medium size, greenish yellow, sweet, good quality. December.

Roman Stem-Medium size, yellow, of good quality, very productive; tree a slow grower when young.

Stayman's Winesap_ striped, $_{\text {I a rge, }}^{\text {nearly }}$ covered with red; flesh greenish yellow, very juicy and aromac; very good; a strong, spreading grower; a good, early bearer; the best of our late winter apples. January to May.

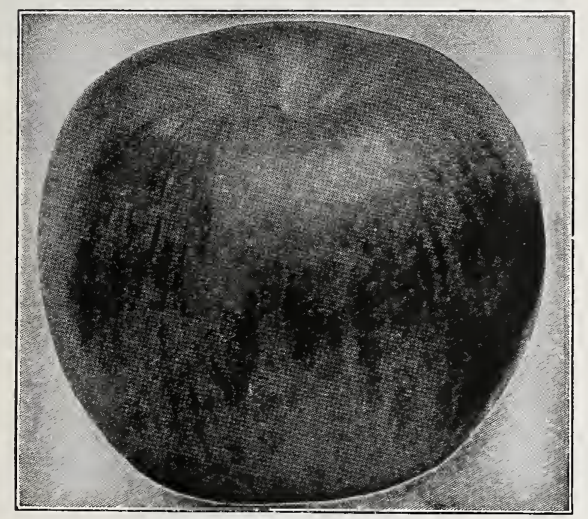

Stayman's Winesap

Tallman Sweet-Medium, pale yellow, firm, rich and very sweet, the most valuable preserving and baking apple; vigorous. October and December.

Winesap-Medium, roundish, deep red, firm, crisp, juicy; excellent quality, moderate grower and good bearer; succeeds well throughout the West. December to May.

Winter Banana-Fruit large, color clear yellow, overspread with pink; red-blushed; flesh yellow, very rich and juicy; tree subject to blight. November to January.

\section{DWARF APPLES}

Set trees 8 to 10 feet apart. Very productive; usually start bearing the second year after planting. Excellently adapted to yard or small garden.

We have four good varieties to offer in the dwarf apple:

Yellow Transparant (Summer).
Wealthy (Fall).
Jonathan (Early Winter).
Delicious (Winter).

Two year, 4 to $5 \mathrm{ft}$., $75 \mathrm{c}$ each. The 4 varieties for $\$ 2.50$. Postage $10 \mathrm{c}$ each; the 4 for $20 \mathrm{c}$.

\section{A Splendid Farm Collection}

Here is an assortment of fruit trees for the farm or a city home, with a little extra garden room, or fine for a city lot.

1 Early Harvest Apple.

1 Snow.

1 Duchess.

1 Jonathan.

1 Delicious.

1 Delicious Dwarf.

1 Early Richmond Cherry.

1 Montmorency Cherry.

1 Bartlett Pear.

1 Opata Plum.

1 Apricot.

2 Elberta Peach.

1 Champion Peach.

1 Magna Charta Rose

2 Bridal Wreath, 2 to $3 \mathrm{ft}$.

\section{$\$ 9.45$ value for

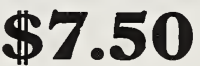

by express only.

\section{CRAB APPLES}

First-class; 4 to $6 \mathrm{ft}$. trees, $50 \mathrm{c}$ each.

Transcendant- ${ }_{\text {with blush; flesh firm, }}^{\text {Large golden }}$ crisp, yellowish; fine grained, very juicy and acid. Popular for jelly and preserves. Trees grow rapidly and irregular; great bearer.

Hyslop-Large, round, yellow, with heavy shadings of deep crimson; blue bloom; flesh fine, firm, yellow. Its high color always commands a fancy market price. Bears abundantly and in clusters.
Tree hardy and vigorous. September and October.

Whitney-Fruit very large, yellow striped with red, flesh yellow, very juicy and fine grained, flavor rich and almost sweet. August.

Sweet Crab-Large size, sweet, good bearer; whitish yellow. Fine for preserves and pickles. September. 


\section{PEACHES}

Our Peaches are all Alpha grown and surely are a fine lot. They will be sure to please. Our prices are extremely low for these high quality trees.

$\begin{array}{lccr} & \text { Each } & \text { Per } 10 & \text { Per } 100 \\ \text { 1st size-4 to } 6 \mathrm{ft} . & \$ .40 & \$ 3.50 & \$ 25.00 \\ \text { 2nd size-3 to } 5 \mathrm{ft} . & .30 & 2.50 & 18.00\end{array}$

Elberta_The great American market peach; produces big, profitable crops. Fruit large, bright, attractive, yellow with crimson shading; flesh firm and of good quality. Will ripen perfectly when picked green. One of the best for home or market use. Free stone. September.

Early Elberta-Smaller than Elberta, fruit yellow; of very good quality. Tree hardy and good bearer. Ripens about ten days earlier than Elberta.

Golden-Good size, golden yellow inside and out, of very good quality. Tree very hardy and a good bearer. Has proven to be a good variety here. September 10 to 15.

J. H. Hale - Of large size, ripens earlier than Elberta, and is of good quality. Color, golden yellow inside and out, with a red cheek. Ripens in September.

Wilson-Fruit large, yellow with large blush. Flesh yellow and juicy. Ripens ten days earlier than Champion. Originated in Mercer County. Supply limited.

Alexander-Medium size, almost solid red in color-flesh white and juicy. July.

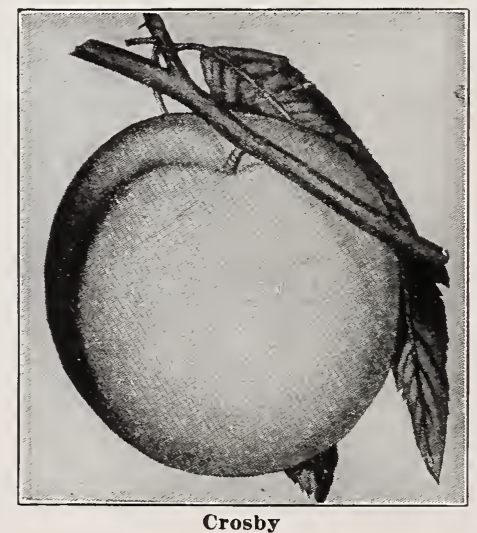

Champion- Fruit large, delicious, sweet, red cheek; handsome, hardy and productive, and a good shipper; adhering slightly to the stone. August 15th.

Crosby-Freestone, medium size, bright yellow, streaked with carmine; annual bearer; hardy. September 15 th.

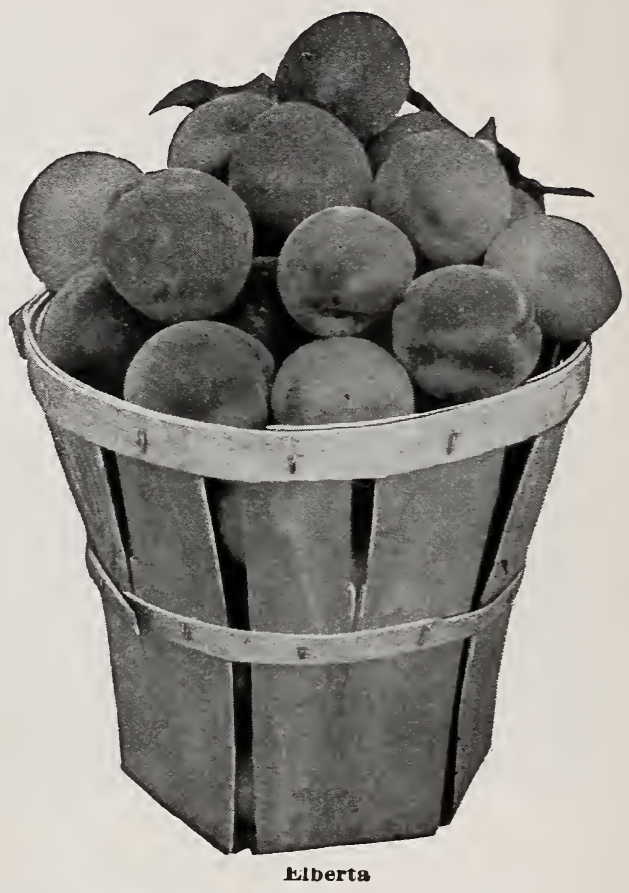

Greensboro-The flesh is white, juicy and delicious quality for so early a peach. The largest and most beautifully colored of all early sorts. July.

Crawford's Early-Freestone, large, yellow; flesh yellow, quality good; tree good grower, but the buds are tender. September.

Lemon Cling-Very large, light yellow; flesh firm, yellow and rich; the great canning peach of the South and West. August.

\section{THIS MAN THINKS HE WAS TREATED FAIR AND SQUARE}

ALPHA NURSERY,

Canton, I11., May 5, 1925.

Alpha, Ill.

Dear Sirs: Your generosity exceeds if possible, even the quality of your plants, and that is saying a great deal, as all the plants without an exception, which we received from you, both last year and this year, are all growing and doing nicely. We thank you for your most generous treatment of us, and will endeavor to show our appreciation by recommending your firm to all who inquire about nursery stock.

S. E. Lacey. 


\section{CHERRIES and PLUMS}

\section{CHERRIES}

5 to $6 \mathrm{ft}$., first class, $\$ 1.00$ each; 6 or more 90c each. Cannot send by Parcel Post.

Early Richmond- Medium, red, early, productive; ripens the last of June.

Large Montmorency- $\mathrm{L}$ a rge; fruit red, sub-acid; of the very best quality; ten days later than the Early Richmond; a fine shaped tree; hardy and productive.

Compass-Cross between a cherry and a plum. Fruit good size, bright red, sweet and juicy of fine flavor. A good early bearing tree, perfectly hardy. 4 to $6 \mathrm{ft}$., $60 \mathrm{c}$ each.

\section{PRUNES}

\section{2 year, 4 to $5 \mathrm{ft}$., $50 \mathrm{c}$ each.}

Italian Prune-Medium large; purplish-black; blue bloom; free; flesh greenish-yellow, juicy, sweet, and of good quality, will hang on tree after ripening; splendid for drying, canning, and market. Tree very productive. September.

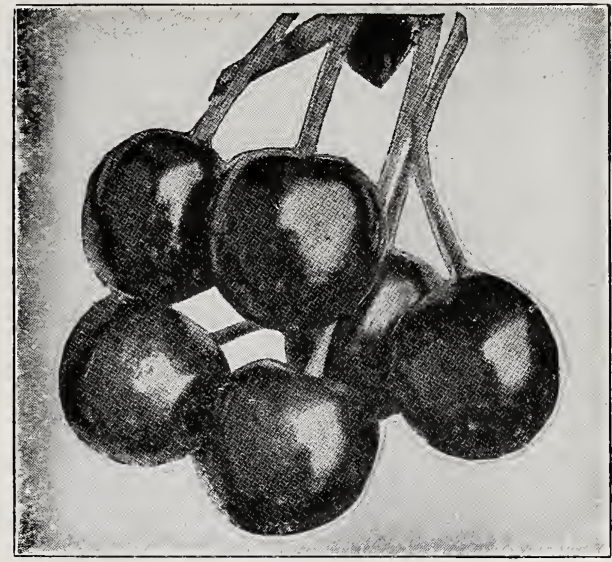

Early Richmond

\section{PLUMS}

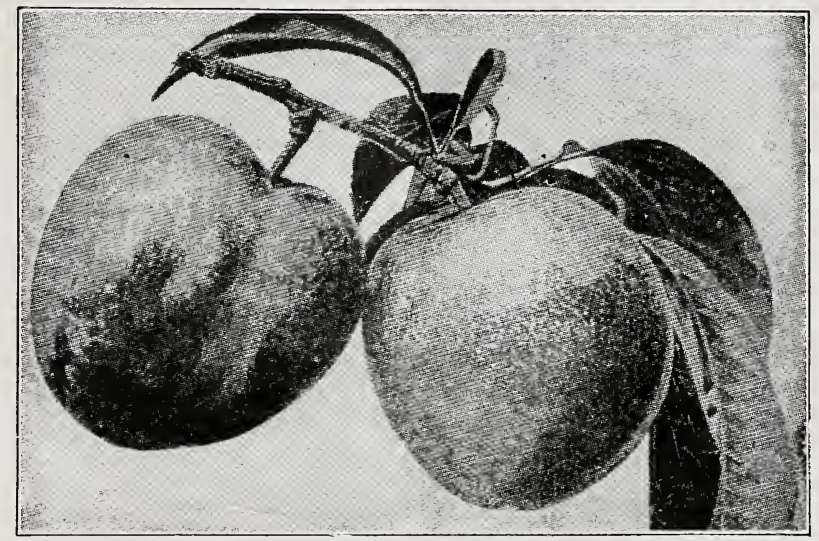

Red June Plum

\section{HANSEN HYBRID PLUMS}

New plums introduced by Professor Hansen, of the South Dakota Experiment Station, at Brookings, who has originated many new fruits, which are of great value and importance to ali sections of the country. One important feature of these Hybrid Plums, is their good quality, extreme hardiness, prolificness and early bearing.

Hanska - Cross between native Plum and Apricot Plum of China, fruit splendid for eating out of the hand, and when cooked, retains the apricot flavor, fruit about one and one-half inches in diameter, red in color, flesh firm, yellow, good quality. Begins to bear the second year. Hardy.

Sapa- Fruit dark purple, thin skin, red and cooking, fine flavor and very prolific bearer. Fruit borne in clusters around the stem; trees three years old have borne as high as one and one-half bushels. Hardy.

Opata_ Dark purplish red. Flesh green, flavor spicy, rich and sweet. Tree vigorous and hardy. A very productive and early bearer. Ripens in July.

Fine 2 year, 4 to $6 \mathrm{ft}$., 50c each; 3 for $\$ 1.40$. 
Abundance_-Medium size, showy, beautiful amber colored, turning to a rich cherry, highly perfumed; flesh light yellow, exceedingly juicy and tender. 2 year, 4 to $6 \mathrm{ft}$., $60 \mathrm{c}$ each.

\section{Blue Damson- Enormously productive.} inch long; skin purple, covered with thick blue bloom; flesh melting and juicy, rather tart, separates partially from the stone. September. 2 year, 4 to $6 \mathrm{ft}$., $60 \mathrm{c}$ each.

Wild Goose_ ${ }_{\text {with }}^{\text {Hardy, native, deep red }}$ yellow, juicy and sweet; rapid grower; early and abundant bearer. July and August. 2 year, 4 to $6 \mathrm{ft}$., $50 \mathrm{c}$ each.

Green Gage-Medium sized yellow freestone, of extra good quality; tree a slow, dwarfish grower. August. $70 \mathrm{c}$ each.
Burbank-Very large, reddish purple; flesh yellow and solid; cling, fine quality, one of the best for canning; tree strong, spreading grower, hardy and productive; subject to rot in wet years. August. 2 year, 4 to $6 \mathrm{ft}$., $60 \mathrm{c}$ each.

Red June-A vigorous, hardy, upright, spreading tree; as productive as abundance. Fruit medium to large, deep vermilion red, with handsome bloom; very showy, flesh light lemon color, slightly sub-acid, of good and pleasant quality; pit small. Early. 2 year, 4 to $6 \mathrm{ft}$., $60 \mathrm{c}$ each.

Yellow Egg-Fruit large, yellow, fair quality; fine for canning; tree a good grower and very productive; the best of the yellow plums for this climate. September. 70c each.

Guii-Fruit large, purplish blue; flesh yellow, firm and sweet; freestone; tree hardy and a strong grower. It has done the best here of any of the large blue plums. September. 70c each.

\section{PEARS}

Good 2 year, 4 to $6 \mathrm{ft}$. trees, $70 \mathrm{c}$ each; $\$ 6.50$ per 10 .

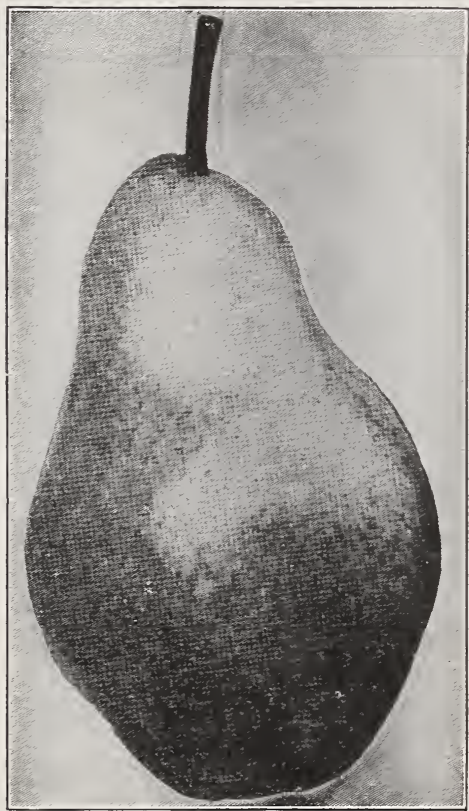

Kieffer Pear

Kieffer_ While not of the best quality, it is one of the favorite varieties for canning and preserving. A very profitable market sort, on account of its good keeping and shipping qualities. Of extraordinary size and beauty. $60 \mathrm{c}$ each.

Bartlett _ Large size, color rich yellow, with often a beautiful blush next the sun; buttery, very juicy, and highly flavored. September.
Duchess-Very large; dull, greenish yellow, streaked and spotted with russet; flesh white, buttery and very juicy, with a rich and very excellent flavor. October.

Lincoln-Large; golden yellow; quality only medium, distinctive as having very few if any seeds, almost clear of core. Tree good grower and productive.

Seckel-Small, yellow: with crimson cheek; flesh melting sweet and aromatic; most exquisitely flavored pear known. Tree slow grower, but hardy and healthy. September.

Dwarf Pears-Bartlett, Duchess, Seckel, Lincoln. These pears commence bearing much earlier than the standards. 4 to $5 \mathrm{ft}$. trees, price same as standards.

\section{QUINCE}

Quince (Orange)-The quince is in very high favor because of its many uses, such as canning, preserving, and flavoring other fruits. This variety is golden yellow, flesh firm, of good flavor; bears abundantly. 4 to $5 \mathrm{ft}$. trees, $\$ 1.00$ each.

\section{APRICOTS}

Apricots-The apricot is a very welcome fruit, ripening between the cherry and peach; it requires the same treatment as the plum; good bearer; fruit like orange, flecked with red. Flesh tender, juicy, sweet and good. 3 to $5 \mathrm{ft}$. trees, $50 \mathrm{c}$ each. 


\section{GRAPES and GARDEN FRUITS}

\section{ASPARAGUS}

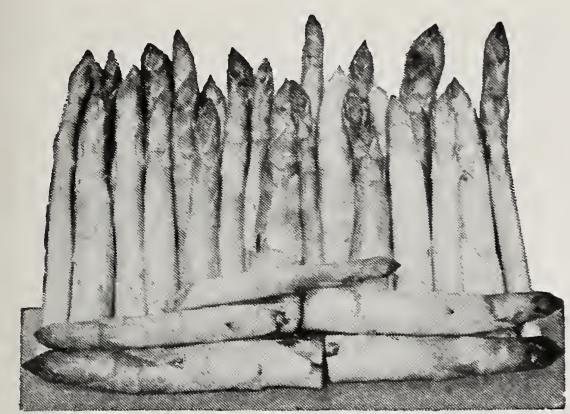

Postage, 10c per 12; 20c per 50.

Conover's Colossal Asparagus-Produces large, tender roots of vigorous growth. 2 year roots, 35 c per $12 ; \$ 2.00$ per 100 .

Washington-A new rust-resistant pedigreed Asparagus. As a standard variety for the production of fancy Asparagus for the home or market, it stands ahead of all others in size, vigor, tenderness, quality and rust-resistance. Washington, 1 year plants, per $12,40 \mathrm{c}$; per $100, \$ 2.50$; per 1000 , $\$ 12.00$.
PIE PLANT

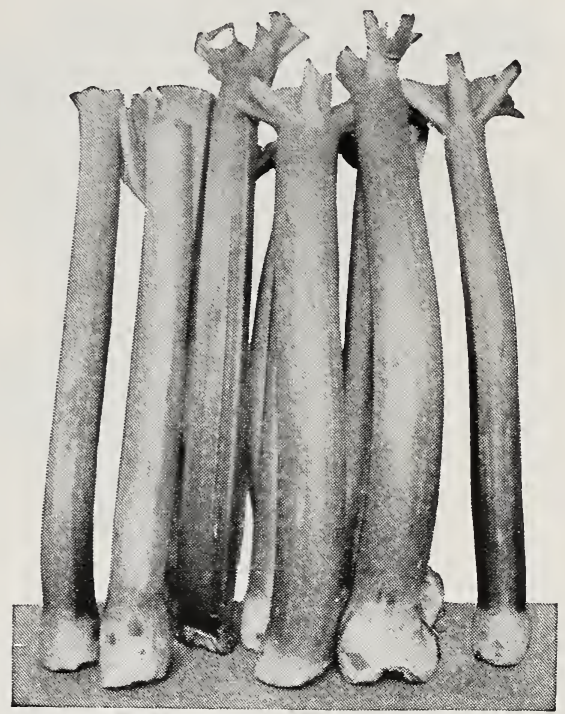

Linnaeus-Large, early, tender and fine, the very best of all. Large two-year-old roots. 10c each; $\$ 1.00$ per 12 . Postage. $6 \mathrm{c}$ for $1 ; 8 \varepsilon, 2$ to 4 roots; $15 \mathrm{c}, 4$ to 8 roots; 20 c for 8 to 12 roots.

\section{GRAPES}

Postage $6 \mathrm{c}$, for 1 to 4 plants; $8 \mathrm{c}, 4$ to 8 plants; $10 \mathrm{c}, 8$ to 12 plants.

Large 2 year Plants.

Concord- Black, the most America; bunches and berries large, hardy, healthy and productive. 15c each; $\$ 1.50$ per $12 ; \$ 11.00$ per 100.

Moore's Early-Black, bunches medium size and very compact; berries large and of excellent quality; ripens ten days before Concord, which makes it very desirable for market; very hardy, well suited for the North; one of the best. 30c each; $\$ 3.00$ per $12 ; \$ 20.00$ per 100.

Campbell's Early-A strong grower. an abundant bearer; bunches and berries very large, glossy black; ripens with the Moore's Early, but will hang on the vines until frost. 40c each; $\$ 4.00$ per 12 .

Agawam-Red or maroon color; berries large;- of rich, pectliar aromatic flavor; ripens a week later than Concord; vine a strong, rank grower. 30c each; $\$ 3.00$ per 12 .

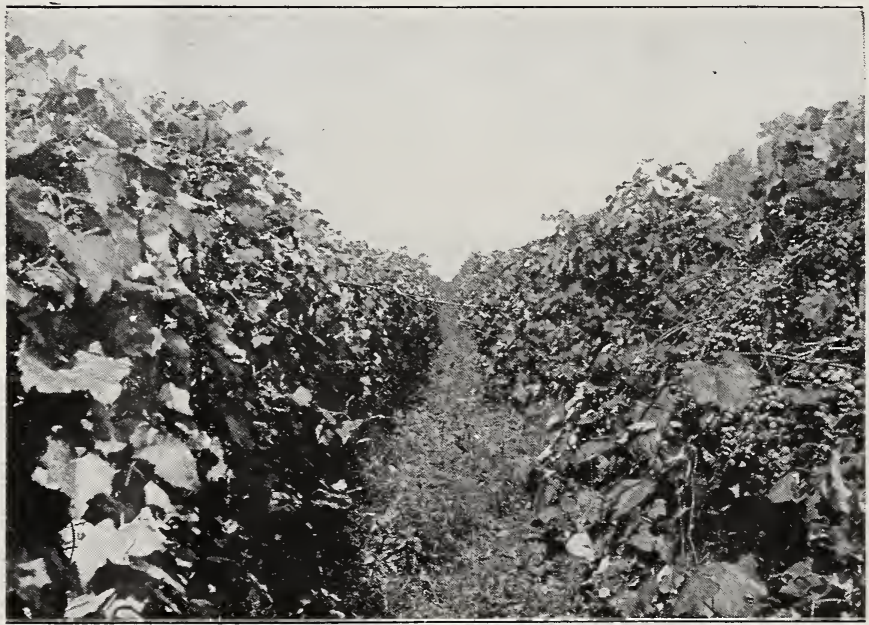

Grapes in Nursery

Moore's Diamond-White buinches and berries, large; flesh tender, juicy; hardy, productive, early; fine quality. 30c each. $\$ 3.00$ fer 12 . 


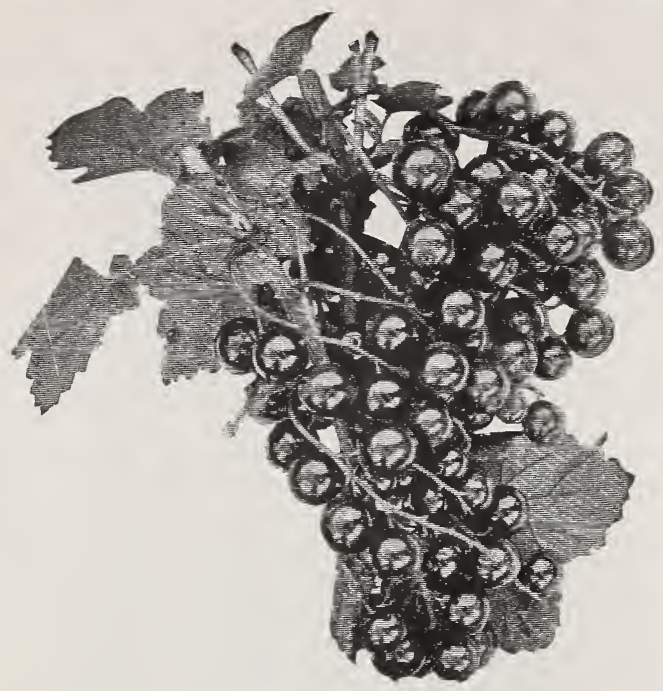

Red Cross

Red Cross-A strong growing variety, with long clusters; berry medium to large, bright red, mild. good quality and a fine flavor. $15 \mathrm{c}$ each; $\$ 1.50$ per 12.

\section{CURRANTS}

Postage $6 \mathrm{c}, 1$ to $4 ; 8 \mathrm{c}, 4$ to $8 ; 10 \mathrm{c}, 8$ to $10 ; 12 \mathrm{c}, 10$ to 12 plants.

All large 2 year plants.

Cherry-Large, deep, red, rather acid, branches short; very productive. 20 c each; $\$ 2.00$ per 12 .

Fay's Prolific-A cross between the Cherry and Victoria; one of the most popular of the red cur. rants, and immensely prolific. 20c each; $\$ 2.00$ per 12.

Pemona-Fruit of good size and flavor, bright red, has long stems and hangs in fine condition after ripening, is a good shipper; bush bears early and is wonderfully prolific; a good market sort. $15 \mathrm{c}$ each; $\$ 1.50$ per 12 .

White Grape-Bush vigorous and productive; clusters long, berries large, very attractive, mild flavor and good quality; a good table variety: distinct from White Dutch. 20c each; $\$ 2.00$ per 12.

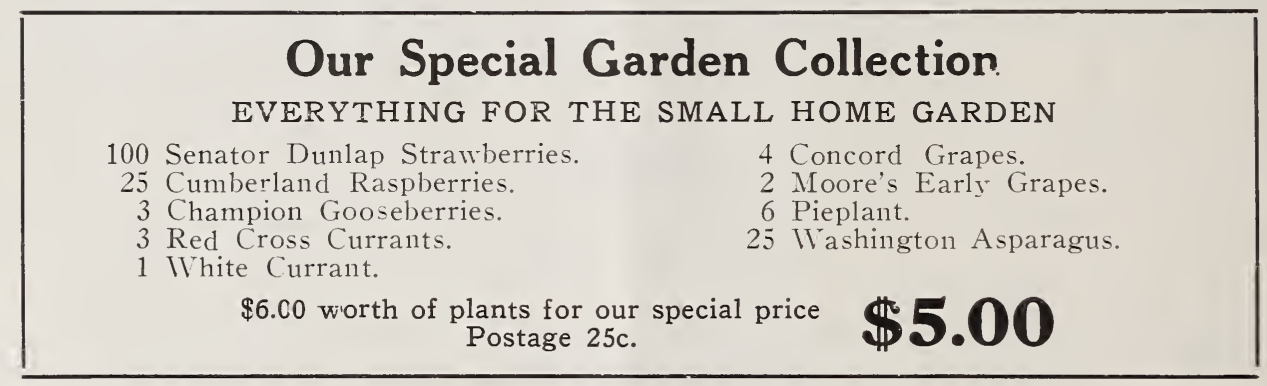

\section{BLACKBERRIES}

Postage, $6 \mathrm{c}$ per $12 ; 15 \mathrm{c}$ per 50.

Eldorado-Among the good points of this val- black, borne in clusters and ripen well together; uable new blackberry, are great productiveness, sweet, melting, rich and pleasant to the taste. hardiness, extra fine quality, and sweetness of Price, $50 \mathrm{c}$ per dozen; $\$ 4.00$ per $100 ; \$ 35.00$ per flavor, without core, the berries are large, jet 1000.

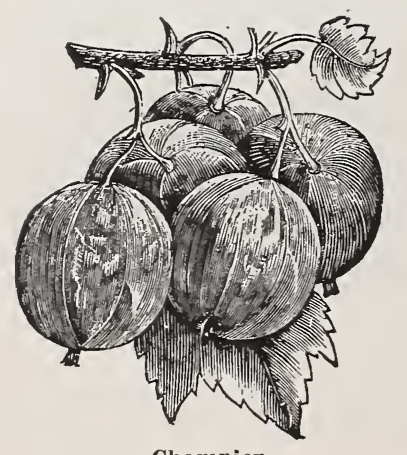

Champion

\section{GOOSEBERRIES}

$30 \mathrm{c}$ each; $\$ 3.00$ per 12

Postage $6 \mathrm{c}$ for 1 to 4 plants; $8 \mathrm{c}$ for 4 to $8 ; 10 \mathrm{c}$ for 8 to 12 plants.

Champion-A variety introduced from Oregon, where it originand enormously productive; fruit round, entirely free from mildew and easily gathered. We consider this the best of the goosberries for general planting.

Pearl-Medium; greenish; quality good; a desirable sort for market also. Bush a strong grower and very productive.

Downing-Native variety, fruit large round, light green, juicy and fine flavored. Smooth skin; Productive. 


\section{STRAWBERRIES}

The following varieties of strawberries are perfect flowering; that is, they do not need any other variety planted near them for fertilizer. We tie all strawberries 25 in a bunch. Write for fall prices. If wanted by Parcel Post, add 5 c for 25 ; 8 c for 50 ; 10 c for 100 plants.

\section{Senator Dunlap_ Fruit good}

form, beautiful bright red; glossy, firm, splendid keeper and shipper; excellent quality; one of the best for canning; ripens early and continues a long time. 25 plants, 35c; 50 plants, $50 c ; 75$ c per $100 ; \$ 3.50$ per $500 ; \$ 5.50$ per 1000 ; $\$ 25.00$ per 5,$000 ; \$ 40.00$ for 10,000 plants.

Norwood-Extra large and of very fine quality; bright red all the way through, a strong, healthy grower; the best of the large fancy berries. 25 plants, 60c; $\$ 2.00$ per 100 .
Gandy-Extra large and handsome, firm: the very latest; most all of the crop ripens after the Dunlap.

25 plants, 50c; $\$ 1.50$ per $100 ; \$ 6.00$ per 500 ; $\$ 8.00$ per. 1,000 .

\section{EVERBEARING STRAWBERRIES}

This kind of strawberries has proved a success. They are hardy and healthy, make a crop in June and another in the fall.

Progressive-Berries large, firm, and good quality: plant a healthy, strong grower and a good plant maker. This plant seems to be a general favorite. With us the June crop was almost as good as the standard varieties. This variety is the original ever bearer and the best of all, and will give the best satisfaction. 50c per $12 ; 65$ c per $25 ; \$ 2.00$ per 100 .

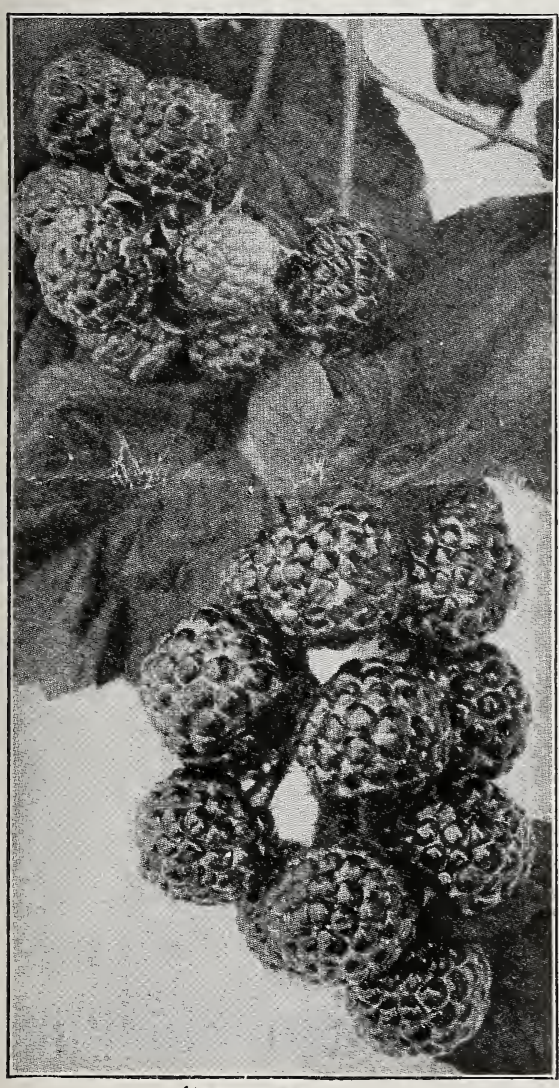

Cumveriang

\section{RASPBERRIES}

Postage 8 cents per $12 ; 15$ cents per 50 ; if within $30 \mathrm{mi}$.

\section{Cumberland - One of the largest black raspberries} and great productiveness entitles it to first consideration. Unusually strong grower, throwing up stout, stocky canes; perfectly hardy. The most profitable raspberry grown for home or market use. Fruits for long season. 50 cents per $12 ; \$ 3.50$ per 100 .

Louden Red-Large size, very firm and hardy, moderate grower, the best of the reds for heavy, rich soil. Sprouts. 50 cents per $12 ; \$ 4.00$ per 100 .

St. Regis (Everbearer)-Very early, fruit large and extra quality, good, stocky grower and hardy. It is very much like the Louden, except it makes a fall crop of the new canes. Red variety. 85 c per $12 ; \$ 2.50$ per $50 ; \$ 4.50$ per 100.

Purple Columbia-Deep purplish red, highly flavored, extra strong canes, wonderfully productive; berries very large. There is nothing finer grown in the line of fruit than this variety for table use, canning, etc. This variety does not sprout. $\$ 1.00$ per $12 ; \$ 1.75$ per $25 ; \$ 3.00$ per $50 ; \$ 5.00$ per 100.

Raspberries are tied 25 to the bunch the top canes are left 6 to 10 inches long, for the sole purpose of tying them in bunches, and after planting this cane generally dies, and the plant starts from the crown or root. In planting, spread the roots out good, cover the crown from 2 to $2 \frac{1}{2}$ inches with soil. Do not put manure next to the roots. Cultivate good the first year, then mulch heavy along the row.

\section{DEWBERRIES}

Lucretia-A trailing blackberry, larger and juicier than blackberries. Fruit ripens ten days before blackberries. For the best success, cover them in the fall like strawberries; in the spring, take the mulching off and put it under them to keep the berries off the ground, and shorten the runners to eighteen inches. Prices $75 \mathrm{c}$ per 12 ; $\$ 2.7 .5$ per 50 ; $\$ 4.00$ per 100 . Postage 8 c per $12 ; 15$ c per 50 . 


\section{NORWAY SPRUCE}

A lofty elegant tree, of perfect pyramidal habit; remarkably elegant and rich; and as it gets age, has fine, graceful, pendulous branches. It is exceedingly picturesque and beautiful.

Much used for foundation planting, where taller Everegreen is wanted, as at the corner or each side of the entrance; also fine for the Shrubbery border, and for windbreaks. They will stand pruning, thus can be made into many shapes.

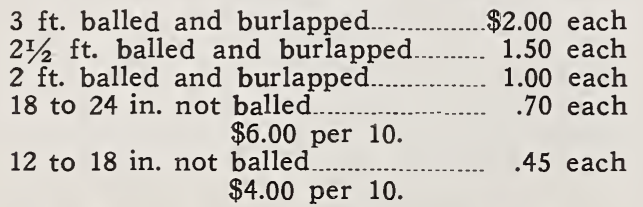

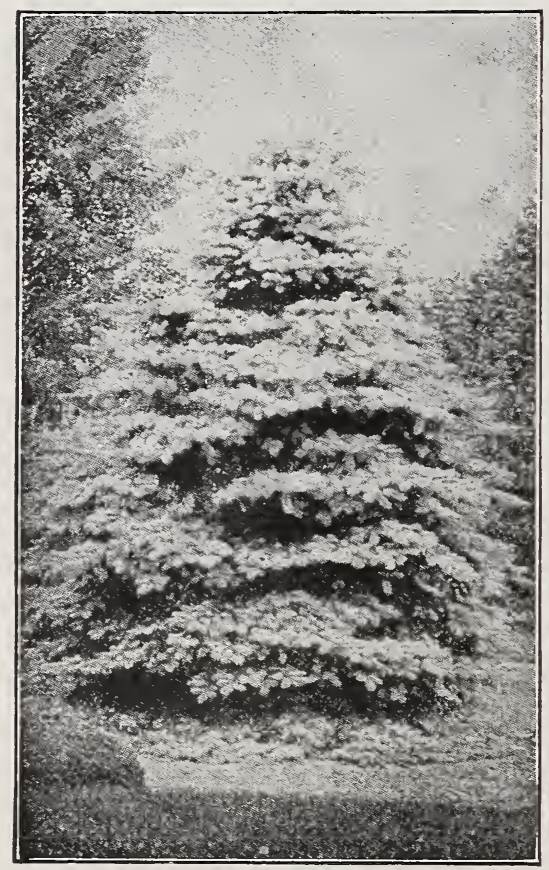

Norway Spruce

\section{A SAVING FOR YOU}

We have a small block of evergreens that we have to move this spring, and we are offering them to you at a very low price.

Blue and Green Cedars-

3 to $3 \mathrm{I} / 2 \mathrm{ft}$.

2 to $3 \mathrm{ft}$.

$\$ 1.50$ each 1.00 each

Norway Spruce-

2 to $21 / 2 \mathrm{ft}$.

$\$ .75$ each

Colorado Blue Spruce (P. Pungens)-A type of the Colorado Blue spruce; it is the highest colored and most striking of all the Evergreens for lawn planting; the foliage is a rich and beautiful silverblue; very hardy. 12 to 16 in., $\$ 5.00$ each.

\section{BLUE CEDAR}

(Juniper Glauca)

The fascinating native Red Cedar that is compared to the classic Cypress. The upright habit, the silvery tint of its foliage and the freedom with which it grows in unfertile places, are valuable qualities.

Color changeable from dark to light blue. Splendid for planting at the corner of foundations, each side of the walks, drives, etc., as fine for accents in the shrubbery border.

4 to $4 \mathrm{~T} / 2 \mathrm{ft}$. Select B. \& B. Fine Trees $\$ 4.00$

3 to 4 ft. B. \& B............................. 3.00

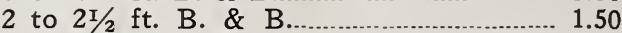

16 to 18 in. B. \& B................................ 1.00

\section{GREEN CEDAR}

\section{Juniperus Virginiana}

Same form and habit as above, only the color of foliage is green, which makes a very good contrast when planted with the blue variety.

4 ft. B. \& B.

3 to $31 / 2 \mathrm{ft}$. B. \& B.

$\$ 3.00$

2 to $21 / 2 \mathrm{ft}$. B. \& B

2.50

\section{ARBOR VITAE}

Globosa (Globe Arbor Vitae)-Round, compact form and dense foliage; very hardy; does well planted in tubs for winter porch decorations. 12 to 14 in., $\$ 1.25$ each.

Pyramidal Arbor Vitae (T. Oscidentalis var. pyramidalis) - A densely branched variety, forming a perfect column; holds its shape without trimming or pruning; hardy and will succeed anywhere the American Arbor Vitae does; a very ornamental type for many kinds of planting. 14 to $16 \mathrm{in}$., $\$ 1.50$ each.

\section{AMERICAN ARBOR VITAE}

This tree is very unique in its habits of growth, the leaf gradually hardening and forming the wood of the tree; habit upright; much inclined to branch and form more than one trunk; one of the best trees for orna.mental hedging; also fine for foundation planting, as it can be trimmed in almost any shape. When trimmed into low round balls, make a pretty effect in front of larger trees and shrubs.

2 to $2 \mathrm{I} / 2 \mathrm{ft}$. B. \& B.

$\$ 1.50$

$2 \mathrm{ft}$. B. \& B.

1.00

18 to 24 in. not balled.................... \$ .70 each $\$ 6.00$ per 10 .

12 to 18 in. Hedge size ................ \$ .40 each $\$ 3.50$ per $10 ; \$ 30.00$ per 100 .

\section{IRISH JUNIPER}

This is another pyramidal form evergreen. It has many branches coming up and form a very straight, compact tree. The silver color makes it desirable. It seldom attains a height of over 4 or $5 \mathrm{ft}$. Fine for all forms of planting.

2 ft. B. \& B. Excellent Trees................ $\$ 3.00$

1 to $1 \frac{1}{2}$ ft. B. \& B. Excellent Trees....... 2.00 


\section{SHADE TREES}

Poplar, Norway or Carolina-One of the most rapid growing trees, with large, deep green leaves; succeeds everywhere, especially adapted to cities, where it makes a fast growth, and resists smoke and gas. It makes a spreading head and dense shade when properly trimmed. 10 to $12 \mathrm{ft}$., $\$ 1.25$ each; $\$ 10.00$ per $10 ; 8$ to $10 \mathrm{ft}$., $75 \mathrm{c}$ each; $\$ 7.00$ per $10 ; 5$ to $7 \mathrm{ft}$., $40 \mathrm{c}$ each; $\$ 3.50$ per 10 .

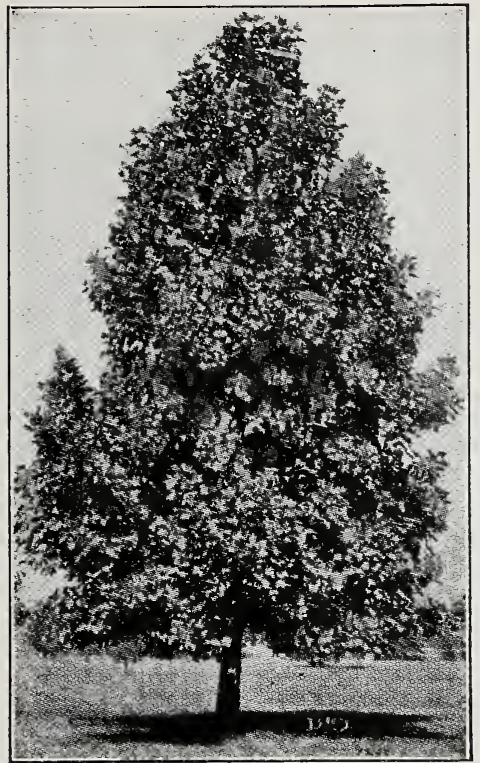

Sycamore

Elm-White, the noble, drooping, spreading tree of our woods; one of the grandest of park or street trees. 10 to $12 \mathrm{ft}$., $\$ 1.25$ each; $\$ 10.00$ per $10 ; 8$ to $10 \mathrm{ft}$., $90 \mathrm{c}$ each; $\$ 7.50$ per $10 ; 6$ to $8 \mathrm{ft}$., $60 \mathrm{c}$ each; $\$ 5.00$ per 10 .

Moline Elm-This tree is becoming very popular, it is a straight upright grower, very picturesque, hardy and long lived. 6 to $8 \mathrm{ft}$., $\$ 2.25$ each.

Sycamore-A lofty, wide-spreading tree; heartshaped leaves; valuable for its handsome foliage and free growth. 4 to $5 \mathrm{ft}$., $75 \mathrm{c}$ each.

Norway Maple-A native of Europe; a large, handsome tree, with broad, deep green, shining foliage. Very similar to hard maple, but faster growing. 6 to $8 \mathrm{ft}$., $\$ 2.00$ each; 8 to $10 \mathrm{ft}$., $\$ 2.50$.

Hard Maple- Spreading top and very for street, park or lawns. 5 to $6 \mathrm{ft}$., $\$ 1.50 ; 8$ to $10 \mathrm{ft}$., $\$ 2.00$ each.

\section{Schwedlers Maple- (A. Platanoides}

This is the beautiful tree with reddish purple leaves that is so much admired. Our trees are straight whips, no branches, cut the top off where you wish the head to form. 6 to $7 \mathrm{feet}, \$ 2.50$ each; 5 to $6 \mathrm{ft} ., \$ 2.00$ each.

Crab- (Bechtel's Double Flowering) - A flowers are fragrant and double, resembling miniature roses, color pink. 2 to $3 \mathrm{ft}$., $\$ 1.00$ each.

Lombardy Poplar (P. Fastigiata)_Atfifty to one hundred feet; well known for its erect, rapid growth and tall spiry form; indispensable tree for landscape gardening, to break the monotony of most other trees. 6 to $7 \mathrm{ft}$., $65 \mathrm{c}$ each; $\$ 6.00$ per $10 ; 4$ to $6 \mathrm{ft}$., $40 \mathrm{c}$ each.

Linden. American-A stately tree, growing 60 to 80 feet tall, with large, shining cordate leaves. Valuable for its beautiful white wood; flowers in July. 5 to $6 \mathrm{ft}$., $85 \mathrm{c}$ each.

Redbud (Cercis)-Judas Tree-A medium sized tree with large irregular head shaped leaves; derives its name, Red Bud, from the profusion of delicate, reddish-pink blossoms with which it is covered in early spring before the foliage appears. 5 to $6 \mathrm{ft}$., $\$ 1.00$ each.

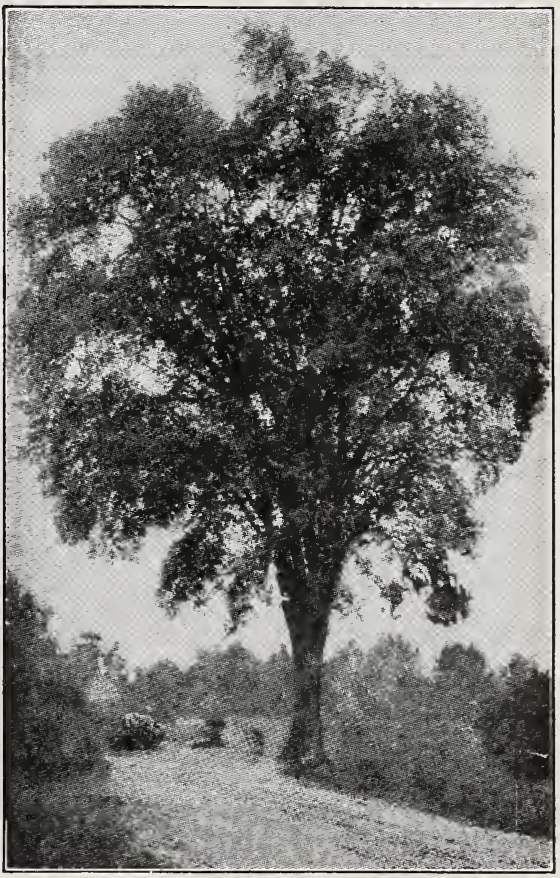

Elm 
Olive, Russian-Tree attains a height of from 20 to 30 feet; bark dark green; wood very heavy and burns like a candle; foliage rich silver color, willow shape; flowers deep golden and very fragrant; hardy. 4 to $5 \mathrm{ft}$., $50 \mathrm{c}$ each.

Tree of Heaven (Ailanthus) -10 to $15 \mathrm{ft}$. More of a tree than shrub. Hardy and very rapid grower. Tropical foliage, long, fernlike leaves; good for background of other shrubs. 4 to $5 \mathrm{ft}$. plants, 75 c each.

Catalpa Speciosa-A rapid grower with large, light green leaves and white flowers in June. 6 to $8 \mathrm{ft}$., $50 \mathrm{c}$.

Catalpa Seedling-These are the hardy Speciosa. For posts they should be planted $4 \times 5 \mathrm{ft}$., and given good cultivation for two or three years. $\$ 2.50$ per $100 ; \$ 7.00$ per 500 .

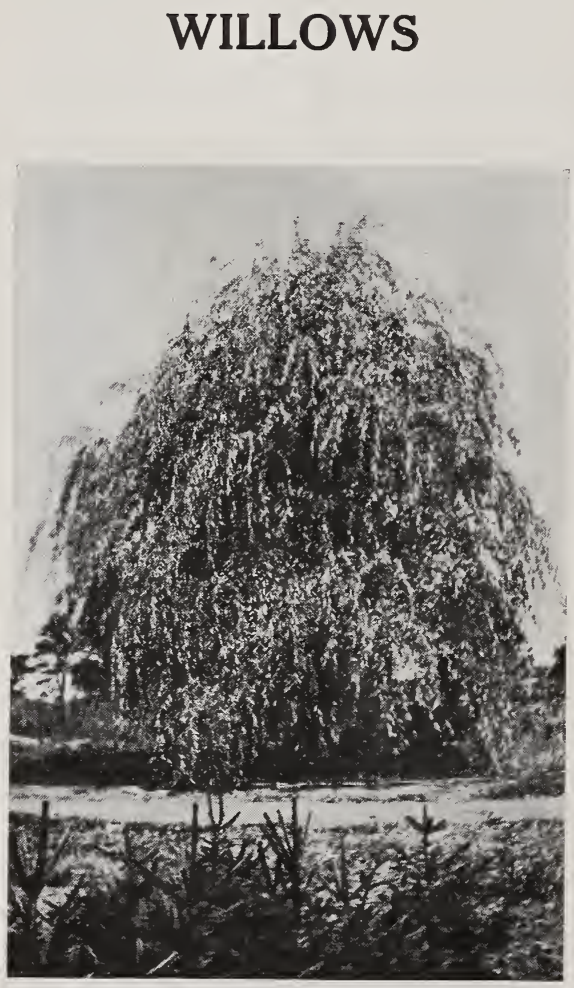

Wisconsin Willow in Nursery

Willow, Wisconsin (Weeping)-A very graceful tree of large size. Its fresh, bright green tint and long, wavy branches, makes it very attractive. Very hardy. 5 to $6 \mathrm{ft}$. trees, $75 \mathrm{c}$ each.

\section{CATALPA BUNGEII}

Catalpa Bungeii (Umbrella Catalpa) Grafted on stems six to eight feet high, it makes an umbrella-shaped top, without pruning; perfectly hardy; leaves large, glossy, heart-shaped, deep green; lay like shingles on a roof.

6 to $8 \mathrm{ft}$., $\$ 2.00$ each.

5 to $6 \mathrm{ft}$., $\$ 1.50$ each.

4 to $5 \mathrm{ft}$., $\$ 1.00$ each.

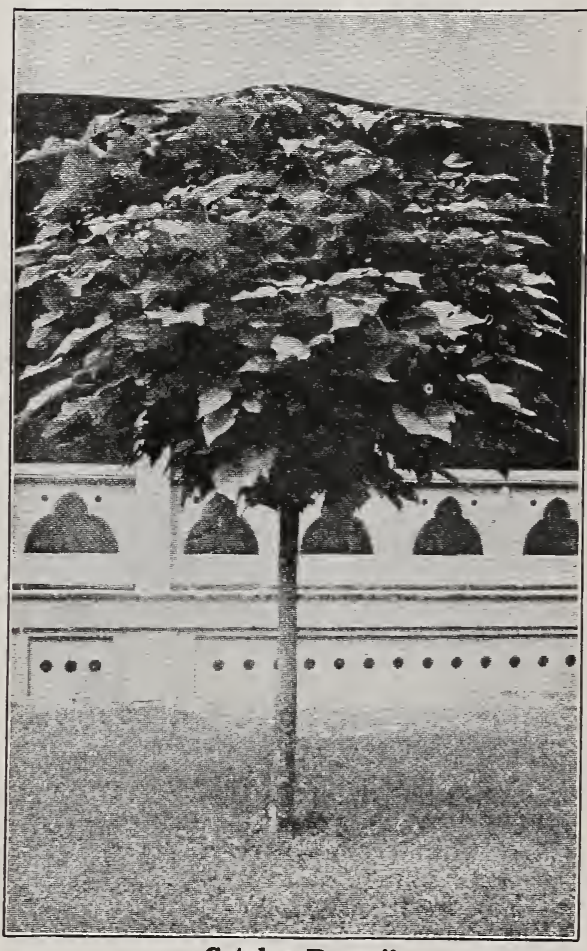

Catalpa Bunzeli

\section{MULBERRIES}

Mulberries, Russian-Tree ornamental, as well as productive; bears very large, handsome black fruit of rich flavor. 6 to $8 \mathrm{ft}$. trees, $75 \mathrm{c}$ each.

\section{CHESTNUTS}

American Sweet-The nuts of this tree form quite an item in our commerce. They are sweet and delicately flavored. This chestnut is also a grand timber and ornamental shade tree. 5 to $6 \mathrm{ft}$ trees, $\$ 1.00$ each. 


\section{THE BEST HEDGE AND BORDER SHRUBS}

Barberry (Thunberg's or Japanese)-The finest of all the Barberries, grows in compact form, spiney stems, foliage fine and dense, changing to brilliant red in fall, the clusters of red berries hanging on all winter. Much used for hedge and borders. Considered by many to be the most valuable foreign shrub grown. This Barberry is recommended by the Government. It does not have the wheat rust. 18 to 24 in., 35c each; $\$ 3.20$ per $10 ; \$ 30.00$ per 100.12 to 18 in., $30 \mathrm{c}$ each; $\$ 2.80$ per $10 ; \$ 25.00$ per $100 ; 10$ to 12 in., $10 \mathrm{c}$ each; $\$ 1.00$ per $12 ; \$ 8.00$ per 100 .

American Arbor Vitae Evergreen-A native of the North; very hardy and will stand shearing well any time of the year; the most popular for hedges and screens, as it keeps green the year round. 12 to 18 in., 40 c each; $\$ 3.50$ per $10 ; \$ 30.00$ per 100 .
Privet Amoors River North-A valuable shrub for hedges and borders, color glossy green, holds its foliage almost the whole year; will stand trimming to almost any extent; perfectly hardy. 3 to $3 \mathrm{r} / 2 \mathrm{ft} ., 40 \mathrm{c}$ each; $\$ 3.00$ per $10 ; \$ 25.00$ per 100 . 2 to $3 \mathrm{ft}$., $30 \mathrm{c}$ each; $\$ 2.50$ per $10 ; \$ 20.00$ per 100 . 18 to 24 in., 25c each; $\$ 2.00$ per $10 ; \$ 17.00$ per 100 . 12 to 14 in., 10 c each; $\$ 1.00$ per $12 ; \$ 8.00$ per 100 .

Spirea Van Houtii (Bridal Wreath)-Used for tall hedges or screens. Has abundance of small white flowers early in the summer. 2 to $3 \mathrm{ft}$., $40 \mathrm{c}$ each; $\$ 3.50$ per $10 ; 18$ to 24 in., $35 \mathrm{c}$ each; $\$ 3.00$ per $10 ; \$ 25.00$ per 100 . 14 to 20 in., $25 \mathrm{c}$ each; $\$ 2.00$ per $10 ; 18.00$ per $100 ; 12$ to 14 in., $10 \mathrm{c}$ each; $\$ 1.00$ per $10 ; \$ 8.00$ per 100 .

\section{Postage -2 to $3 \mathrm{ft}$. sizes, $5 \mathrm{c}$ each; $15 \mathrm{c}$ for $5 ; 25 \mathrm{c}$ for 10 . 18 to 24 in. sizes, $5 c$ each; 10 c for $5 ; 20$ c for 10 . 12 to 18 in. sizes, $5 \mathrm{c}$ each; $10 \mathrm{c}$ for $5 ; 15 \mathrm{c}$ for 10 . 12 to 14 in. sizes; $10 \mathrm{c}$ for 12 plants}

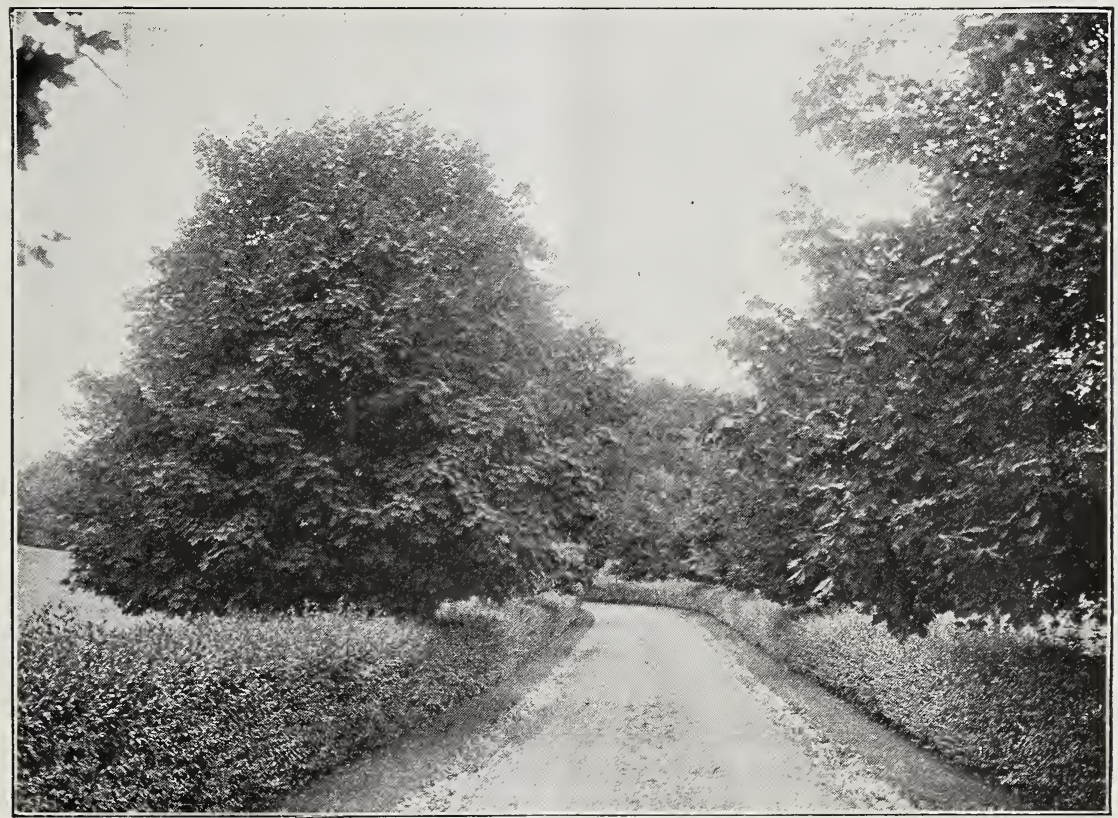

Privet-Hedge and Norway Maples

Why not fix up the Home this spring, now is a good time to start that hedge. The shrubs we list on this page are all hardy and will stand 40 below zero; all they require is a little cultivation the first year, and after that, trimming. Our prices are very reasonable and our stock first-class.

Come to the Nursery and look the plants over. 


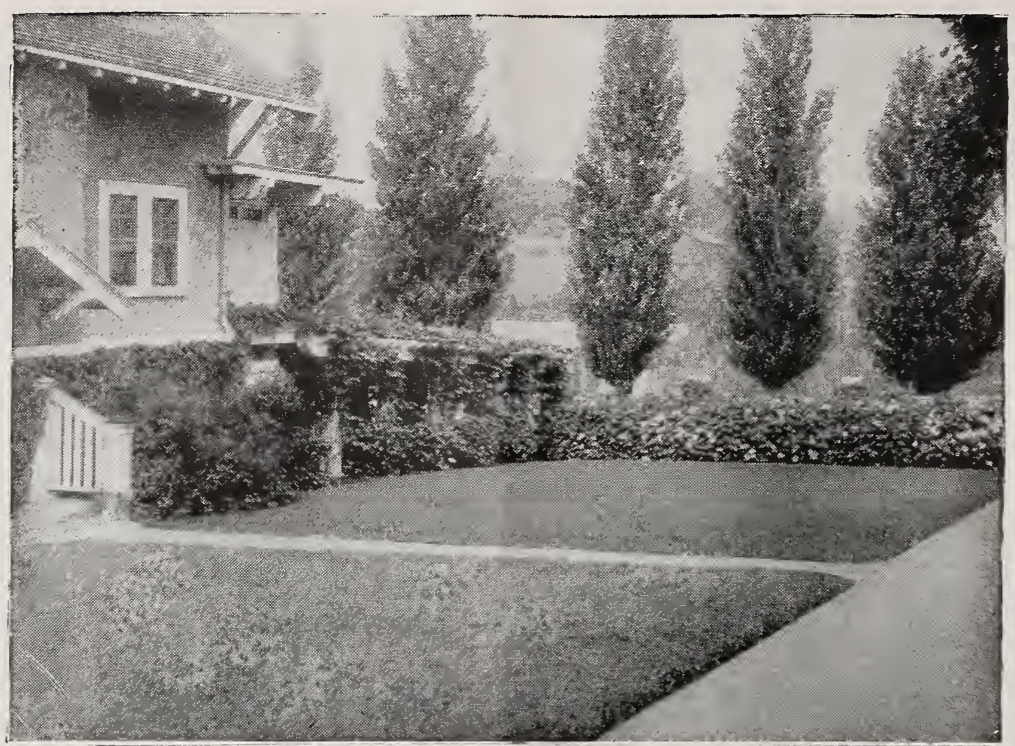

Hydrangias and Lombardy Poplars

In the adornment of the home grounds, hardy shrubbery has come to be recognized as indispensable, and it is a pleasure to be able to offer the quality of stock which will be found listed on the following pages. Its uses are many and varied. To set about the foundations of the house, to grow as hedges, to divide properties, or as screens to hide unsightly objects, to supplement the planting of evergreens or shade trees, shrubbery has its distinctive place. The proper planting of shrubbery about the home adds to its value many times the amount expended.

Althea (Rose of Sharon)-Grows 3 to $4 \mathrm{ft}$. A free flowering shrub, blooms in August and September; flowers resemble double hollyhocks. Foliage very attractive. Need protection through winter. Colors-white, purple, red and rose. $2 \mathrm{ft}$., $50 \mathrm{c}$ each.

Arrowwood-8 to $12 \mathrm{ft}$, has bright green heart shaped leaves, which turn to purple and red. Creamy white flowers followed by blue fruits which cling to the branches a long time. 2 to 3 ft., 50c each. 18 to 24 in., $45 \mathrm{c}$ each.

Almonds, Double White (Amygdalus Alba)Grows 3 to $5 \mathrm{ft}$. White flowers like small roses; blooms early; decorative. 2 to $3 \mathrm{ft}$., 90c each.

Almonds, Double Pink (Amygdalus Rosea)Same as above, except flowers pink. 2 to $3 \mathrm{ft}$, $90 \mathrm{c}$ each.

Aralia Spinosa_ Grows 6 to $8 \mathrm{ft}$. A rugged shrub, with large decidedly tropical looking leaves. Branches thickly covered with long spines. Flowers appear in large masses; white to yellow. A picturesque plant. 2 to $3 \mathrm{ft}$., $50 \mathrm{c}$ each.
Berberis Thunbergi- (Japanese Barberry - The Barberry is used extensively, where a good
divarf, bushy hedge is desired. Every branch is thickly studded with short thorns, and it is often purchased on this account. The foliage turns to a brilliant red in September, which is followed in the winter by scarlet berries, which help to make it an attractive shrub the year round. It is not susceptible to wheat rust. 18 to 24 in., $35 \mathrm{c}$ each; $\$ 3.20$ per 10 . 12 to 18 in., $30 \mathrm{c}$ each; $\$ 2.80$ per 10 . See page 15 for 100 lots. (See back for specials).

Crab-(Bechtel's Double Flowering), $\$ 1.00$ each. See page 13.

Calycanthus, Sweet Scented-Grows 3 to $5 \mathrm{ft}$. The wood is fragrant, rich; flowers are chocolate color, having a peculiarly agreeable odor. Blooms in June and at intervals afterwards. 2 to $3 \mathrm{ft} ., 50 \mathrm{c}$ each.

Cranberry High Bush (Viburnum Grows 6 to $8 \mathrm{ft}$. Foliage lustrous green, changing to rich copper; blossoms in May, with clusters of flat-topped white flowers, followed by scarlet berries. 2 to $3 \mathrm{ft}$., $60 \mathrm{c}$ each.

Deutzia Crenata-Double white flowers; blooms in May and June. Attains a height of 2 to $4 \mathrm{ft}$. 18 to 24 in., 50 c each.

Deutzia Lemoine-Grows 3 to $5 \mathrm{ft}$. Single white flowering, spreading habit, fine branches and leaves; blooms early in the summer. 18 to 24 in. plants, 50c each.

Deutzia (Pride of Rochester)-Grows 4 to $6 \mathrm{ft}$. Blooms early in the spring, with extra large white flowers; one of the hardiest of the Deutzia. 18 to 24 in. plants. $50 \mathrm{c}$ each. 


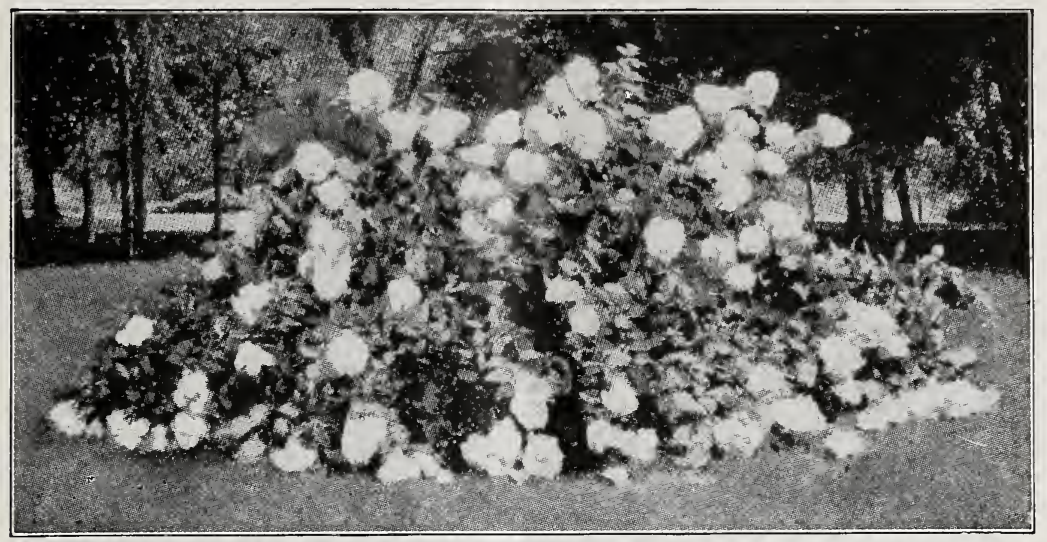

Hydrangia Planting

Dogwood Red (Cornus Siberica)-Grows foliage, pale on the underside; blooms rarly in the summer, with clusters of flat-topped creamy white flowers, followed by light bluish fruit; branches are dark red; very attractive shrub. 2 to $3 \mathrm{ft}$., $50 \mathrm{c}$ each. 18 to 24 in., $40 \mathrm{c}$ each.

\section{Dogwood Yellow (Cornus L u te a) -} very pretty shrub for winter color effect; bark bright yellow, foliage a pea green. 2 to $3 \mathrm{ft}$. plants, $45 \mathrm{c}$ each.

\section{Elder Golden (Sambucus Aurea)-Grows} golden yellow foliage, vigorous and spreading grower; flowers white in flat-topped clusters, followed by reddish black berries; grows well on any soil; can be pruned into a neat, compact little bush; best of the golden foliage shrubs. 2 to $3 \mathrm{ft}$. plants, 50c each.
Hydrangia Hills of Snow (A r b orSterillis)-Grows 3 to $5 \mathrm{ft}$. A new variety, much like the above, but commences to bloom in July and lasts until frost; flowers borne on long stems, and changing from pure white to green, a rare variety. 18 to 24 in. plants, $60 \mathrm{c}$ each.

Kerria White (Rhodotypos Kerrioides)-Grows 3 to $5 \mathrm{ft}$. A very ornamental shrub, with bright green foliage, and single flowers in May, followed by conspicuous shining black fruit in the fall. 2 to $3 \mathrm{ft}$. plants, $50 \mathrm{c}$ each.

Kerria Yellow (K. Japonica)-Grows 3 to $4 \mathrm{ft}$. Foliage deep green and very dense, branches vivid green and particularly showy in winter; flowers bright yellow. A very graceful shrub. 2 to $3 \mathrm{ft}$. plants, $50 \mathrm{c}$ each.

Lilac Common Purple (Syringa Vulgaris)-Grows 6 to $8 \mathrm{ft}$. One of the best old time garden shrubs; bluish purple flowers. 2 to $3 \mathrm{ft}$. plants, $45 \mathrm{c}$ each.

Hydrangia P. G. (Paniculata Grandiflora)-Grows 3 to $6 \mathrm{ft}$. This is one in great pinnacles, nearly a foot long, and changing from pure white to rose or bronze in late fall; blooms from August until frosts. 18 to 24 in. plants, 50c each; 2 to $3 \mathrm{ft}$. plants, 60c each.

Golden Bell (Forsythea Fortunei)-Grows 4 to 6 ft. Has yellow, bell-shaped flower, in racemes, very early in the spring before the leaves are formed; up-right in growth; yellow bark. 2 to $3 \mathrm{ft}$. plants, $50 \mathrm{c}$ each.

Golden Bell Weeping (Forsythea Suspensa)Similar to above, but has long, drooping branches; very pretty shrub. 2 to $3 \mathrm{ft}$. plants, $50 \mathrm{c}$ each.
Lilac White (Syringa Vulgaris Alba)-Same as above, except white bloom. 2 to $3 \mathrm{ft}$. plants, $45 \mathrm{c}$ each.

\section{Lilac Persian_Grows 5 to $6 \mathrm{ft}$ - Light} blue flowers, narrow leaves growing on slender branches; finer variety than the above. 2 to $3 \mathrm{ft}$. plants, $50 \mathrm{c}$ each. 


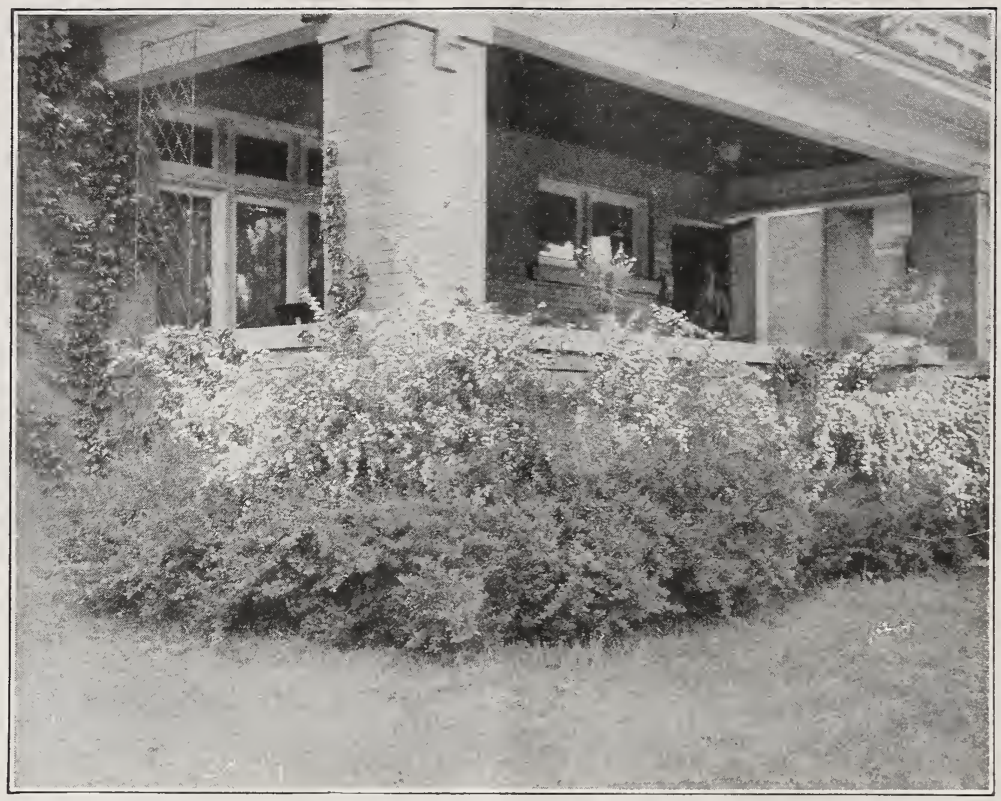

Barberry and Spirea Van Moutii

\section{Privet Amoor River (Ligustrum Am-}

5 to $8 \mathrm{ft}$. Will stand 50 degrees below zero; valuable shrub for hedges and grouping with other shrubs; upright in growth; foliage, glossy green. 2 to $3 \mathrm{ft}$. plants, $30 \mathrm{c}$; $\$ 2.50$ per 10 . 18 to $24 \mathrm{in}$. plants, $25 \mathrm{c}$ each; $\$ 2.00$ per 10 . 10 to 14 in. plants, 10 c each; $\$ 1.00$ per 12 . (See page 15.)

Quince Japan (Cydonia Japonica)-Grows 3 to 4 ft. Very early; in the spring this shrub is covered with dazzling scarlet flowers, followed by small quince-shaped fruit, which are fragrant; grows bushy and dense, with protecting thorns. 18 to 24 in. plants, 50c each.

\section{Rose Rugosa 3 to $5 \mathrm{ft}$. This rose is very} it is fine; the foliage is refined and charming all summer; blossoms large, single, produced throughout the summer, followed by crimson fruits. Very hardy; red flowers. 18 to 24 in. plants, 60c each. Snowball (Viburnum Sterilis)-Grows 6 to $8 \mathrm{ft}$. The common snowball, which blooms the last of May, with lovely white balls of flowers. 2 to 3 ft. plants, 60c each.
Syringa (Mock Orange)-Grows 6 to \& ft. Vigorous habit, very hardy, with large, handsome foliage, and fragrant white flowers in June. 2 to $3 \mathrm{ft}$. plants, 50c each.

Syringa Lemoine-Flowers large, semi-double white. Bush of dwarfish habit. One of the best of our dwarf spring flowering shrubs. 2 to $3 \mathrm{ft}$., $50 \mathrm{c}$.

\section{Snowberry White (Symphoricarpus}

small rose, colored flowers in June, followed by clusters of milk white berries, which remain far into the winter; very pretty winter shrub. 2 to $3 \mathrm{ft}$. plants, $50 \mathrm{c}$ each.

\section{Snowberry Red (Symphoricarpus Vul-} ft. Very much like above, but the berries are red and smaller; sometimes called Indian Currant or Coral Berry. 2 to $3 \mathrm{ft}$. plants. $45 \mathrm{c}$ each.

Spirea Ballardii-Grows 4 to $5 \mathrm{ft}$. Pink flowers, in large spikes; upright in habit, with red brown branches, dull green foliage. 2 to $3 \mathrm{ft}$. plants, $45 \mathrm{c}$ each.

\section{Spirea Van Houtii \\ most beautiful and common shrubs; an immense blowers early in the summer. 2 to $3 \mathrm{ft}$. plants, $40 \mathrm{c}$ each. 18 to 24 in. plants, $35 \mathrm{c}$ each. 14 to 20 in. plants, $25 \mathrm{c}$ each. 12 to 18 in. plants, $\$ 1.00$ per 12. (See page 15.)}

Sumac Cut Leaf (Rhus Typhina)-Grows 6 to 10 $\mathrm{ft}$. A very striking plant of moderate size, with deeply cut leaves resembling fern leaves; dark green, turning to rich red in fall; red impressive fruit in fall and winter. 2 to $3 \mathrm{ft}$., 50c each.
Spirea Ballardii Alba-Same as the above, but the bloom is white. 2 to $3 \mathrm{ft}$. plants, $50 \mathrm{c}$ each.

Spirea Collosa Alba-Grows 1 to $2 \mathrm{ft}$. White flowers in large, flat-topped clusters; blooms most all summer. 12 to 18 in. plants, $45 \mathrm{c}$ each. 


\section{Flowering and

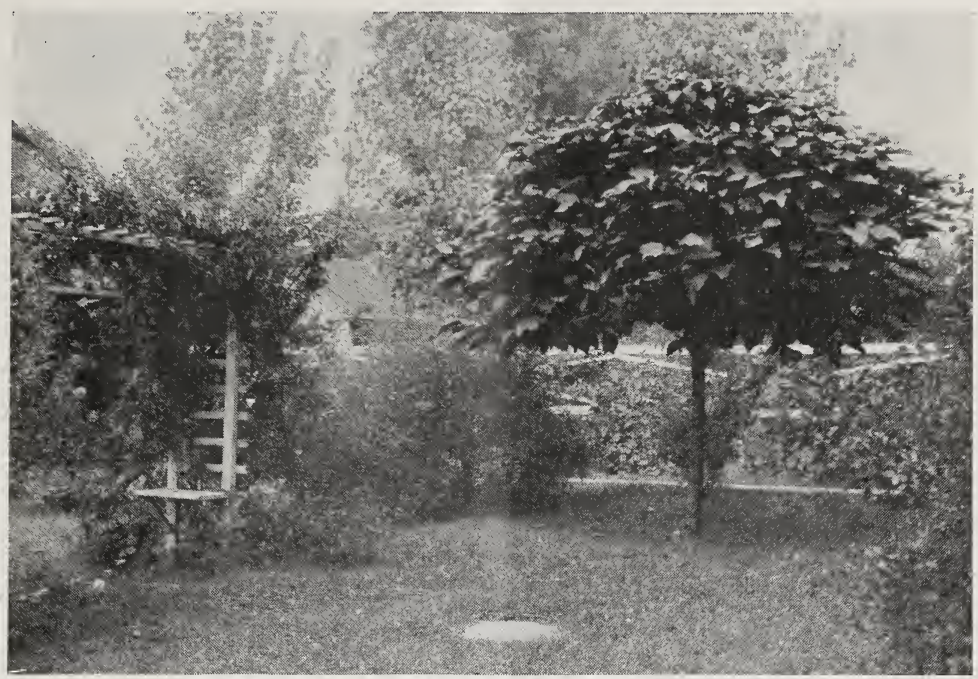

Shrubs Furnished by Us (2nd year)

Spirea Golden (Opulifolia Aurea)-Grows 5 to 8 ft. Upright habit; white, heavy flower umbels in June; old flowers turn to dark red or brown; young foliage, light yellow, turning to dark red or bronze in fall. 3 to $4 \mathrm{ft}$. plants, $50 \mathrm{c}$ each.

Wiegelia Eva Rathke-Grows 3 to $4 \mathrm{ft}$. The most distinct and one of the most attractive varieties. Flowers deep carmine red. 2 to $3 \mathrm{ft}$. plants, $75 \mathrm{c}$ each.

Wiegelia Rosea-4 to $6 \mathrm{ft}$. A tall growing variety, with deep pink flowers in great profusion during June, and at intervals through the summer. 2 to $3 \mathrm{ft}$., $50 \mathrm{c}$ each.

Wiegelia Candida-Flowers pure white and produced in great profusion in June and at intervals throughout the summer. 18 to 24 in., $50 \mathrm{c}$.

Tamarix African Grows 4 to 6 ft. green foliage; pinkish white blooms in June; very picturesque plant. If cut back each year, will make much nicer foliage. 2 to $3 \mathrm{ft}$. plants, 50c each.
Tamarix Blue (Glauca)-Very much like is a delicate misty blue color. 2 to $3 \mathrm{ft}$. plants, 50c each.

Tree of Heaven (Ailanthus)-10 to $15 \mathrm{ft}$. More of a tree than a shrub, but when cut back, each year makes a very desirable shrub. Hardy and very rapid grower. Tropical foliage, long, fernlike leaves; good for background of other shrubs. 5 to $6 \mathrm{ft}$. plants, 75c each.

Spirea Thunbergii-Grows $3 \mathrm{ft}$. Fine, slender leaves and branches, with its profuse blossoms in May. 12 to 18 in. plants, 50c each.

Spirea Anthony Waterer- Grows 2 Dwarf. Flowers, bright crimson; free bloomer, best late in the summer; flowers in round, flattopped clusters; foliage, light green. 12 to $18 \mathrm{in}$. plants, 50c each.

Spirea Froebeli_ Dwarf, similar to Angrows a trifle taller with broader leaves. 18 to 24 in., 50 c each.

\section{Collection of Shrubs}

The shrubs of either of these collections are good for a medium and large size porch, also foundation planting, if you are planning on planting a few shrubs this spring, will pay you to consider one of these collections, as they save you money. The shrubs are all standard No. 1 size.

Collection No. 1-

1 Hydrangia P. G. 2 Spirea V. H.

2 Spirea Frobellia. 3 Barberry.

3 Coral berry.

11 Shrubs value $\$ 4.65$.

Special Price
By Express.
Collection No. 2-

2 Hydrangia P. G. 4 Spirea V. H.

2 Spirea Frobellia. 2 Coralberry.

1 Honeysuckle Bush. 2 Snowberry.

1 Hills of Snow. 6 Barberry.

20 Shrubs value $\$ 8.35$.

Special Price
By Express. 


\section{Three new Shrubs for 2926 ONE OF EACH FOR $\$ 2.25$}

One will not find many of the shrubs in plantings in the Mississippi valley as they are entirely new.

\section{ADD AT LEAST ONE OF EACH TO YOUR PLANTING.}

\section{Syringa Virginalis - A magnificent new variety of the Mock Orange, handsomest and most sweetly scented of any known variety. \$1.00 each.}

Rosia Acacia-Grows 4 to 6 feet. Locust-like leaves and flowers. The flowers are pink and bloom same time as the Bridal Wreath. Very hardy. 2 to $3 \mathrm{ft}$., $75 \mathrm{c}$ each.
Hypericum Aureum-Grows 3 to $4 \mathrm{ft}$. Double yellow flower, July to October. Unusually good foliage, a little hard to transplant, but with pains can be moved all right. A fine low shrub. 2 to 3 ft., $75 \mathrm{c}$ each.

\section{OUR LEADER SHRUBS}

Are listed on the back of the catalogue. They are fine plants, of good size, and will sure please you.

\section{BARGAIN IN GOOD SHRUBS}

The following shrubs, we are offering at a bargain, as we have an over production of these kinds, this year, therefore, we are offering them to you at a very low price. The shrubs are Number ONE QUALITY, Large size and are of the grade that is regularly sold for 50 and 60c each.

SPECIAL PRICE-30c each, 4 for $\$ 1.10$. Add 5c to each shrub for Postage.

Strawberry Tree (Euonymus Europaeus)-Grows 5 to $7 \mathrm{ft}$. One of the finest varieties grown; bark, light green; foliage changes to brilliant colors in fall; spreading in growth. A fine shrub. 2 to 3 ft. plants.

Sumac Smooth (Rhus Glabra)-Grows 5 to $8 \mathrm{ft}$. Beautiful leaves, which color brightly in the fall; flowers in July, followed by crimson or bronze fruit. 3 to $4 \mathrm{ft}$. plants.

Aralia Pentephylla_Grows 4 to $6 \mathrm{ft}$. Valuable for its excellent heavy, bright green foliage. Small greenish white flowers. Good in rocky or sandy places. 2 to $3 \mathrm{ft}$. plants.

Honeysuckle Tartarian (Lonicera T.) -Grows 6 to $8 \mathrm{ft}$. A very attractive, useful shrub, with abundance of fragrant flowers in the spring and bright red fruit in the fall. Somewhat spreading in growth. 2 to $3 \mathrm{ft}$. plants.
Pea Tree (Caragana Arborescens)-Grows 8 to $10 \mathrm{ft}$. A very pretty dwarf tree or shrub, with yellow pea-shaped flowers in May, foliage in light green; very small and fine. 2 to $3 \mathrm{ft}$. plants.

Honeysuckle Morowii (Lonicera M.) $8 \mathrm{ft}$. A Japanese variety, blossoms white, changing to yellow; refined foliage; long blooming period, followed by small berries, upright in growth. 2 to $3 \mathrm{ft}$. plants.

Honeysuckle Fragrant (Lonicera F.)-Grows 4 to $6 \mathrm{ft}$. A very attractive shrub; foliage very pretty, with slender recurving branches. Flowers fragrant, need protection in winter. 2 to $3 \mathrm{ft}$. plants.

Hydrangia P. G. - The hardy 1 a rge bloom turning pink late in the fall, same as the $60 \mathrm{c}$ size, but smaller. 12 to 14 inches. 


\section{Three Eskimo Beauties \\ "The Kind That Grow Where No Others Will" Hybrid Rugosa Roses \\ PINK-WHITE-RED}

Hansa (An Eskimo Beauty)-Handsome in bud and bloom. Both are large, very full and double. The color is rich, maroon-red.
Belle Poitevine (An Eskimo Beauty)and full, the petals gracefully in-curved. Bright, clear, lively pink.

\section{Eskimo Beauties}

The Roses that grow where no others will. $\mathrm{Hy}$ brid Rugosa Roses in which are combined the best qualities of the different rose species.

The Rugosa Rose was introduced $\mathrm{from}$ Japan years ago. It is absolutely hardy, with fine, thick, heavy foliage. But the flowers are single.

By crossing the Rugosa Rose with the best of the double, ever-blooming varieties, a new race has been evolved in which are retained the fine, vigorous growth, the extreme hardiness, the abundant and lasting dark green leaves of the Rugosa type, combined with the size and color of the best everblooming roses.

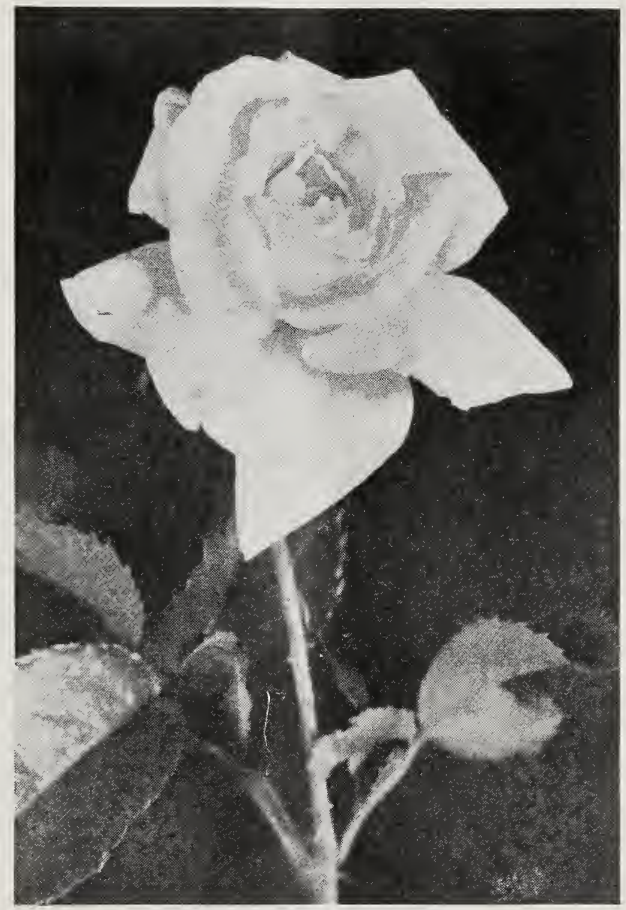

Sir Thomas Lipton (An Eskimo Pure white; no tinge of pink or yellowjust pure white. The flowers are very double and borne in graceful clusters.

\section{Eskimo Beauties}

grow, thrive, and bloom anywhere. They are the ideal cold-climate roses. The plants are on their own roots-grown from cuttings-no tender top to die back, no foreign roots to sucker: root and top are the same variety.

Eskimo Beauties-Rugosa Hybrid Roses-are free from mildew, disease and pests that attack other classes of roses.

They will grow in the South and in the Middle West; they will stand the winters of Minnesota and Wisconsin and the Dakotas without protection; in hardiness and vigor, they are kindred of the Fir and Spruce.

\section{Big Husky Bushes}

Will bloom the first year $\$ 1.00$ each 3 for $\$ 2.50$

Postage 10c for one-20c for 3

The roses are fine for shrubbery border, foundation planting or the rose garden. Don't pass them by as they are sure fine.
Once planted, they are permanent: no pruning, no spraying, no suckering nor anything else is needed-just a little manure spaded in and the ground stirred-and they will last for years and yield an abundance of large, double, fragrant, colorful blooms-the only really good dependable roses for very cold climates. That is why they are called Eskimo Beauties. 


\section{HYBRID PERPETUALS}

Our Roses are all hardy field grown bushes; grown here at our Nursery, and will be full of flowers the first year. They are not to be compared with the small potted roses sometimes offered. We grow the varieties most adapted to this climate, all of these varieties went thru the 26 below zero weather safely last winter; with a good protection of leaves.

In our Special Collection, we are offering our most popular varieties, in a good assortment of colors, at a very low price.

Large two-year, field grown bushes. These Roses will bloom the first year. $\$ 4.00$ for $6, \$ 7.50$ for 12 . Postage 6 c for 1,12 c for 6 .

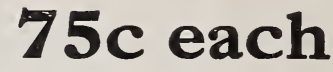

\section{American Beauty- A hardy rose, of} having the ever-blooming qualities of the tea roses; it is the sweetest of all roses; the color is a deep, brilliant rose, shaded to a rich carmine.

\section{Baby Rambler_ The original dwarf form} The wonderful persistency of its bloom makes it one of the choicest plants in cultivation for summer bedding, and as an edging to borders of shrubs, roses or perennials, it has no equal.

\section{Frau Karl Druschki-A pure, paper-} sized and free flowering. The bloom is perfect in form on fine, long stems.

Gen. Jacqueminot-One of the most popular of the red roses, brilliant crimson, large bloom, fragrant and hardy.

\section{Gruss an Teplitz_- Color a rich scarlet,} crimson; very fragrant; a free, strong grower, and the most profuse bloomer known to us, being covered with flowers the whole season. The foliage is extremely beautiful, all the younger growth being a bronzy plum color.

\section{Four Color Collection-}

1 Frau Karl Druschki. 1 Gruss an Teplitz.

1 Paul Neyron. 1 Etoile d Lyon. All for $\$ 2.00$. Postage $15 \mathrm{c}$.

\section{HYBRID TEA ROSES}

Killarney Pink-Flowers intensely fragrant, long pointed buds. Color a clear pink, excellent for cutting and a good bloomer. 75c each.

Killarney White-Pure white form of the above and one of our best bloomers. Very fragrant. $75 \mathrm{c}$. Madam Carolina Testout-Large full rich pink flowers. A good bedding rose, free bloomer. $75 \mathrm{c}$.

June Rose-Double pink, very hardy; makes large bush. Profuse bloomer early in summer. 50c each.

This variety of roses makes a vigorous stocky growth and bloom but once a vear.
Magna Charta-A general favorite, prized on account of its strong, upright growth and bright, healthy foliage, as well as for its magnificent bloom. The color is a beautiful bright pink.

\section{Paul Neyron_ Deep, shining rose, very} fresh and pretty. Flowers large, often measuring five inches in diameter. The buds always develop fine, perfect roses.

Prince de Rohan-Very dark, velvety crimson. A prolific bloomer and flowers are of excellent form and size.

Soleil de Or-A fine, hardy out door rose, especially valuable, because of the rare color; gold and orange yellow, varying to ruddy gold, suffused with nasturtium red.

\section{Duchess of Wellington-Color saf-} low, excellent for cutting, as the buds are long and flowers lasting. The best of the yellow roses.

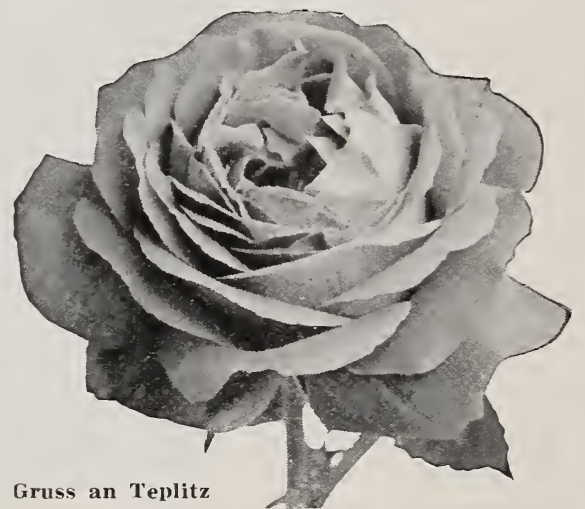

RUGOSA ROSES

Rugosa, Conrad F, Myerrugosa and tea roses, making a very hardy and vigorous grower, with large, double, silvery pink blooms. $75 \mathrm{c}$ each.

Rugosa Rose-A single red rose, blooming at intervals thru the summer. Used more as a shrub. Has dark, rich foliage, oddly wrinkled and remarkably free from insects. Is absolutely hardy and is much used for foundation planting or in the shrubbery border. Flowers are followed by large red berries. 2 to $3 \mathrm{ft}$., $60 \mathrm{c}$ each. 
We offer the following two-year field grown everblooming roses, which are the second size. They are of lighter weight than our regular grade, but are nice strong bushes and will bloom the first year.

\section{5 e each $\stackrel{\text { By mali add } 5 c}{b c}$}

American Beauty-Deep pink to carmine. Large regular flowers that are very durable, thus making it very desirable for cutting.

Frau Karl Druschki-White American Beauty. Beautiful snow white; very large, full, perfectly formed; superb.

General Jacqueminot (Jack Rose)-Brilliant s c a r l e tcrimson; very fragrant and an early bloomer.

Paul Neyron-Very large; deep rose; a favorite, the largest flower among Hybrid Perpetual Roses.

Soleil d' Or (Golden Sun)A new hardy yellow rose. Flowers full and globular; very fragrant.

Baby Rambler-The original dwarf form of crimson rambler. The wonderful persistency of its bloom, makes it one of the choicest plants in cultivation for summer bedding, and as an edging to

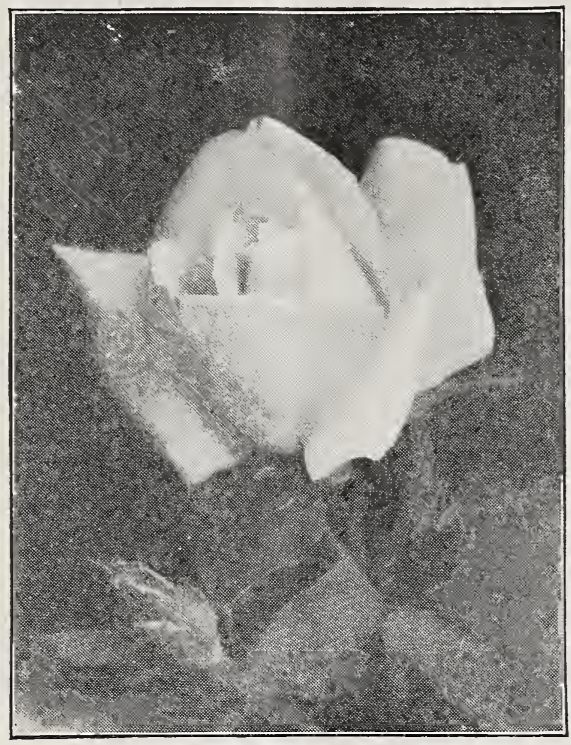

Frau Karl Druschki borders of shrubs, roses of perennials, it has no equal. Killarney Pink-Flowers intensely fragrant, long pointed buds. Color a clear pink. excellent for cutting and a good bloomer.

Killarney White-Pure white form of the above, and one of our best bloomers. Very fragrant.

Madam Carolina TestoutLarge, full, rich pink flowers. A good bedding rose, free bloomer.

La France-Silvery rose, changing to pink. Exceedingly sweet and handsome. Blooms soon after planting. Etoile de Lyon-Flowers large and full, with broad petals. Color, chrome yellow. Very fragrant. One of the finest.

Gruss an Teplitz-Intense depth and richness of color; velvety crimson-red. One of the best dark garden Roses.

\section{Climbing Roses: $60 \mathrm{c}$ each $\begin{gathered}\text { Large } 2 \text { year } \\ \text { field grown plants }\end{gathered}$}

Climbing American Beauty-Much like the bush form of this name, except it has the climbing habit.

\section{Ercelsa (Red Dorothy Perkins)-A radiant,} are very large and fairly cover the vines. It is best to plant this variety where crimson rambler is not hardy.

Dorothy Perkins-Beautiful shell pink, full and double; large size for a cluster rose; it is a hardy, strong grower.

Multiflora Rose-Double, pink; strong grower; very hardy, profuse bloomer. Good where shade is wanted, also where other Roses fail to grow. $45 \mathrm{c}$ each.

Thousand Beauties (Tausendschon) - Colors of every imaginable shade, from pure white to deep pink. Almost thornless.

Blue Rambler (Veilhenblau)-The flowers are a violet blue; the buds show some red, but quickly change as they open.
The Illinois Rose (Rosa Setigera)_Large, single, pink, blossoms in July; beautiful foliage, absolutely hardy. The stem turns red in winter, which together with quantities of crimson fruit, produce a charming winter effect.

Prairie Queen-The flowers are very large and of peculiar globular form; bright, rosy red; changing to lighter as the flower opens. Of strong, rapid growth.

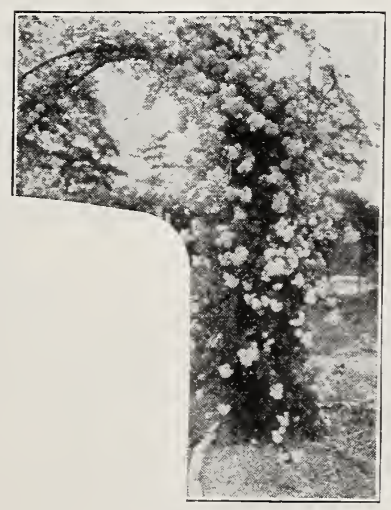

Ercelsa
Crimson Rambler-It is a vigorous grower; flowers glowing and produced in immense panicles.

Paul's Scarlet Climber-Winner of gold medal as best new climbing Rose, at National Rose Society's Exhibition. Flowers are scarlet, shaded crimson; large, semi-double. Corresponds with Cl. Am. Beauty. Dr. Van Fleet, etc., as to size, shape and habit. Blooms very long, holding in flower after many June bloomers have dropped their petals; a wonderful Rose for trellis or pergolause. Mail 75c; Express $70 \mathrm{c}$. 


\section{CLIMBING VINES}

Strong two-year, 35c each

Honeysuckle, Scarlet Trumpet-One of the handsomest in cultivation; coral flowers; very vigorous and hardy; blooming all summer.

Trumpet Vine (Tecoma Radicans)-Handsome, dark green foliage and showy clusters of orange and scarlet flowers during the summer.

\section{Dutchman's Pipe (Sipho) - A strong growing vine, with} immense heart-shaped leaves and peculiar pipeshaped flowers. This vine makes a fast, heavy growth, and is fine for the porch or trellis. Hardy. These plants are grafted from a blooming plant therefore are sure to bloom. $\$ 1.00$ each.

Bittersweet-A native vine that is especially ornamental in fall and winter, with brilliant orange and scarlet fruit.
Chinese Matrimony Vine-A strong, hardy climbing vine. Bright, rosy-purple flowers, followed by brilliant scarlet berries.

\section{Wisteria (Purple)} One of the finest climbers, of rapid growth, and perfectly hardy, with long, pendulous clusters of bluish purple. Flowers in June.

\section{Engleman's Ivy - It is one of the finest} brilliant coloring of the leaves in autumn, together with perfect hardiness, makes it a valuable climber for covering brick or stone walls. Where hardiness is necessary, the Englemani will be found much superior to Boston ivy.

American Ivy-The well known native vine with five parted leaves, that change to rich crimson in áutumn; berries blue black; very rapid grower and perfectly hardy.

Postage on all plants on this page, $6 \mathrm{c}$ for 1 to 3 plants; $8 \mathrm{c}$ for 3 to 6 plants.

\section{CLEMATIS}

Beautiful free flowering vines, with very showy flowers. They are well adapted for training on porches, balconies and trellises. For covering walls, fences and arbors.

Jackmanni- The well-known large-flowering blue Clematis. measure 4 to 6 inches in diameter, intense violet-purple, with a rich, velvety appearance, distinctly veined. It blooms continually from July, until cut off by frost. Plant is hardy, abundant and successful bloomer. 2 year field grown plants, $75 \mathrm{c}$ each; 1 year pot plants, 50c each. The pot plants cannot be shipped until after May 1st, as they are green and growing.

Henryi-This is the finest of all large-flowering white Clematis, and should find a place in every collection. It is not only a vigorous grower, but a remarkably free and continuous bloomer, beginning with the earliest, holding out with the latest. Flowers are large, of beautiful creamy-white, with reddish-chocolate anthers. 2 year, field grown plants, $75 \mathrm{c}$ each.

Panticulata - The small-flowering, sweet-scented Japan beauffful of all climbers. It is a rapid of the most vigorous and a quick-growing vine is needed, on walls, verandas, fences, etc. In late summer, it produces dense sheets of medium-sized, pure white flowers, of the most pleasing fragrance. Will grow in almost any soil and is entirely free from blight and insects. 2 year field grown plants, 50c each; 1 year pot plants, 25c each. Shipment after May 1 st, for the pot plants.

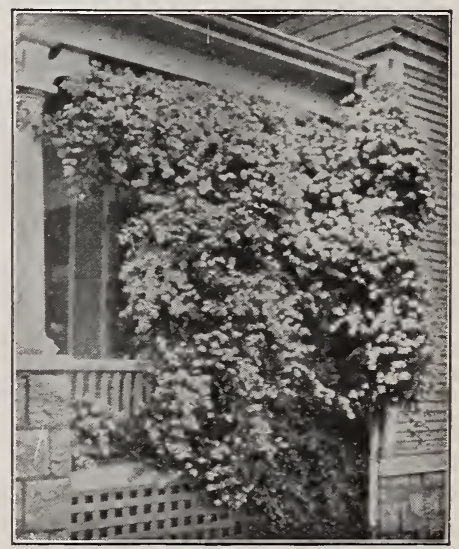

Paniculata

If you have been having a hard time to start clematis, try our pot plants. They are started in the greenhouse, trained up on stakes, and about May 1st, we ship them to you with the earth on the roots and the vine in leaf, and if the plant is properly taken care of everyone should grow. 


\section{$\underset{\text { Garden }}{\text { Harly }}$ FLOWERS}

\section{PERENNIALS}

Perennials have never been so popular as at the present time. Once planted and always there. The great variety of color and the blooming period, which extends from May until frost, makes perennials very desirable for all forms of planting. We offer a large assortment of one and two years field grown plants. Perennials can be planted from April 1st to May 15th, or about the middle of September in the fall. Perennials can be sent by express or parcel post, and should be planted as soon as received.

If wanted by Parcel Post, add $6 \mathrm{c}$ for 1 to 5 plants; $8 \mathrm{c}$ for 6 to 10 plants; 10 c for 10 to 12 plants. If within 300 miles of our nursery.

Bleeding Heart-Charming hardy perennial plant, with much cut foliage. Pink flowers of interesting structure. One of the choice members of old-fashioned gardens. 50c each; $\$ 5.00$ per 12 .

Chrysanthemum (hardy)-Will flower successfully in any garden, and will furnish an abundance of bloom in September and October, after all other flowers are gone.

Pink-Flowers borne in great masses, each flower 2 to $2 \mathrm{r} / 2$ in. across.

Yellow-Flowers borne in great masses, each flower 2 to $2 \mathrm{r} / 2$ in. across.

White-Flowers borne in great masses, each flower 2 to $2 \mathrm{I} / 2$ in. across. Dwarf variety.

Bronze-Bronze colored flowers, 1 to $1 \frac{1}{2}$ in. across. This one is sure fine.

Bronze Button-A beautiful golden bronze color, flowers $3 / 4$ to 1 in. across, and the plant is literally covered with flowers, (fine).

$25 \mathrm{c}$ each, 3 for $60 \mathrm{c}, \$ 2.00$ per 12 .

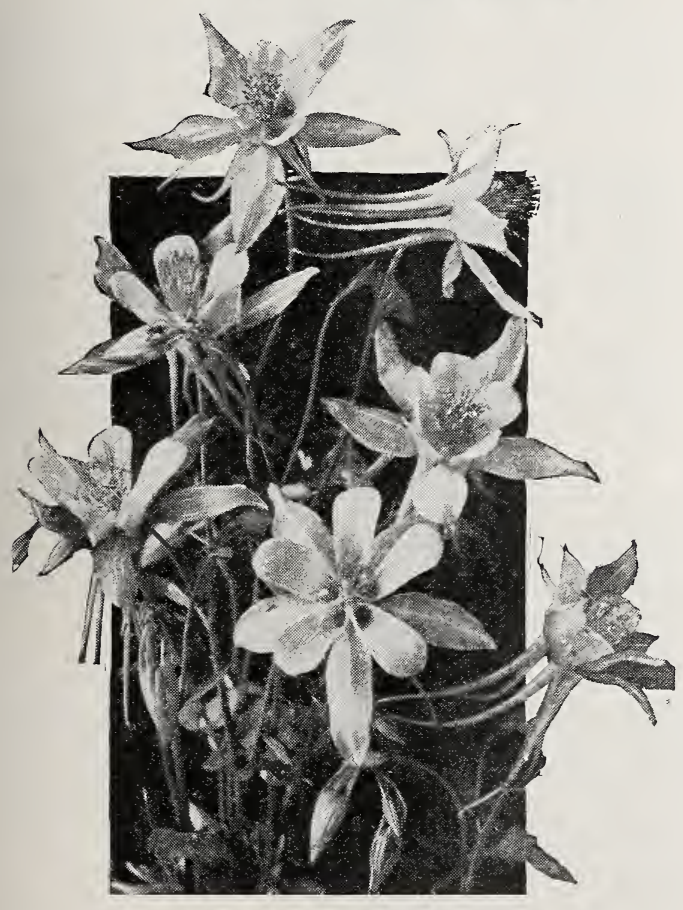

Columbine (Aqulegia) Long Spurred HybridsA new form of an old favorite. The graceful spurred flowers on two foot stems are valuable for cutting. Colors range from white and yellow to blue. Bloom in early spring; mixed colors. Good two-year plants, $15 \mathrm{c}$ each; $\$ 1.50$ per 12 .

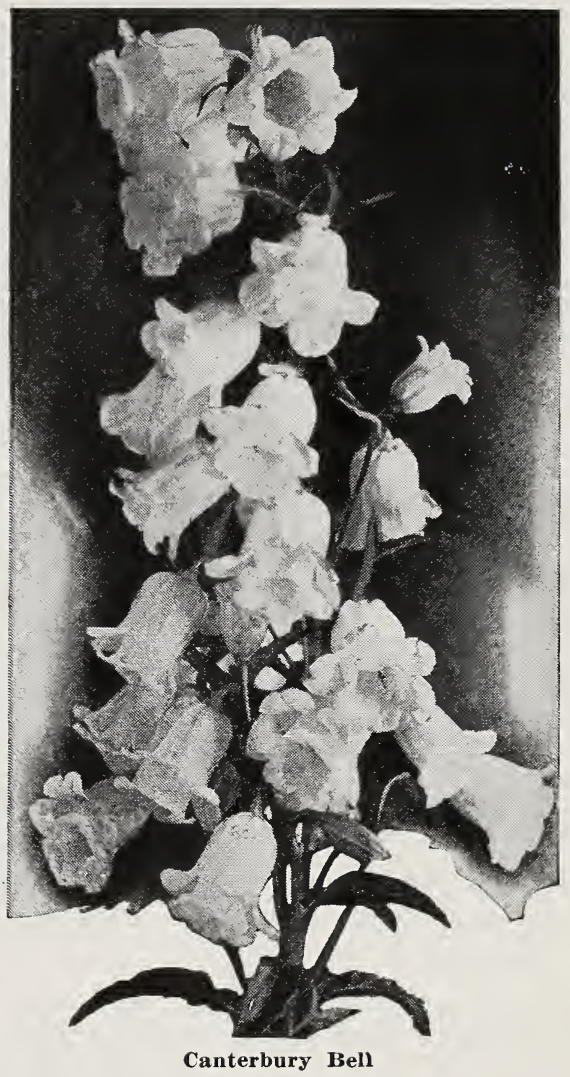

Canterbury Belle- One of the ful of the old-fashioned garden plants, has tall spikes of bell-shaped flowers in June. Our plants are mixed colors this year, therefore we are making a very low price on these big two year plants The colors are pink, blue and white, but we cannot tell them. 20c each; $\$ 2.00$ per 12 .

\section{Desmodium Penduliflora}

A very pretty semi-herbaceous shrub, which is overlooked in planting many gardens, it grows 2 to 4 feet, and is literally covered in the fall with long drooping racemes of lavender flowers. Don't pass this shrub by, as it is fine, you will like it. $50 \mathrm{c}$ each. 
If wanted by Parcel Post add $6 \mathrm{c}$ for 1 to 5 plants; $8 \mathrm{c}$ for 6 to 10 plants; $10 \mathrm{c}$ for 10 to 12 plants. If within 300 miles of our nursery.

\section{Delphinium}

(Perennial Larkspur)-If we could have but one plant in our garden, it would be one of these. Their greatest charm lies in their stateliness of growth and the beautiful blue of their flowers. Very hardy and easy to grow. Sky blue and dark blue flowers on four foot stems, blooming in July and again in the fall. Light Blue or Dark Blue 20c each; $\$ 2.00$ per 12 .

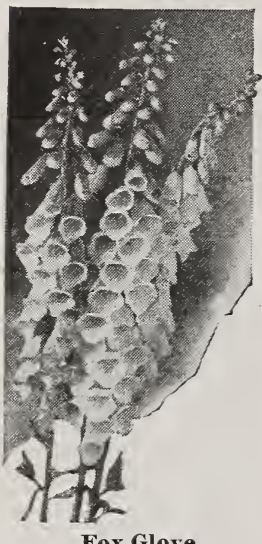

Fox Glove
Fox Glove (Digitalis)-Stately old-fashioned border plant, growing 3 to $4 \mathrm{ft}$. high, with handsome thimble-shaped flowers on long spikes; mixed colors. 20 c each; $\$ 2.00$ per 12 .

Butterfly Bush (Buddleya Variabilis Magnifica)-Often called summer lilac. This shrub from a young plant set out in the spring, will mature to full size the first summer, making a handsome bush. It produces tapering panicles of beautiful lilac colored flowers on long, graceful stems. Strong field grown plants. No. 1 plants, $40 \mathrm{c}$ each. No. $1 \mathrm{I} / 2$ plants, $30 \mathrm{c}$ each.

Golden Glow-Hardy clear yellow flowers produced in great quantities on long stems. Resemble golden Cactus Dahlias. Bloom in July and August. $15 \mathrm{c}$ each; $\$ 1.50$ per 12.

Gallardia (Blanket Flower) - The most flowers. Perfectly hardy and will stand much neglect. Blooms continually from June to October. Flowers crimson bordered with orange. $15 \mathrm{c}$ each; $\$ 1.50$ per 12 .

Hibiscus (Meehan's Mallow Marvels)-A magnificent new strain of hardy Mallows, which for size and profusion of bloom, and richness of coloring are among the most striking and beautiful perennials that grow. Flowers 8 to 10 inches in diameter. Bloom in July and August, when flowers are scarce. Separate colors-Red, white, and pink. $35 \mathrm{c}$ each. Postage on 1 plant $6 \mathrm{c}$, and add 1c for each additional plant.

Lily of the Valley-Small white flowers, very fragrant. Will grow in shady, cold ground, where grass will not do well. $70 \mathrm{c}$ per 12 .

Lily Day-Yellow, very hardy. Grows 1 to $1 \frac{1}{2} \mathrm{ft}$. 10c each.

Hardy Aster (Novi Belgii)-Plant is dense, bushy, about 30 inches high, with very ornamental fine cut, dark green foliage. Unlike most top blooming sorts, this variety blooms profusely clear up from the ground; delicate pasted pink. 20c each; $\$ 2.00$ per 12 .

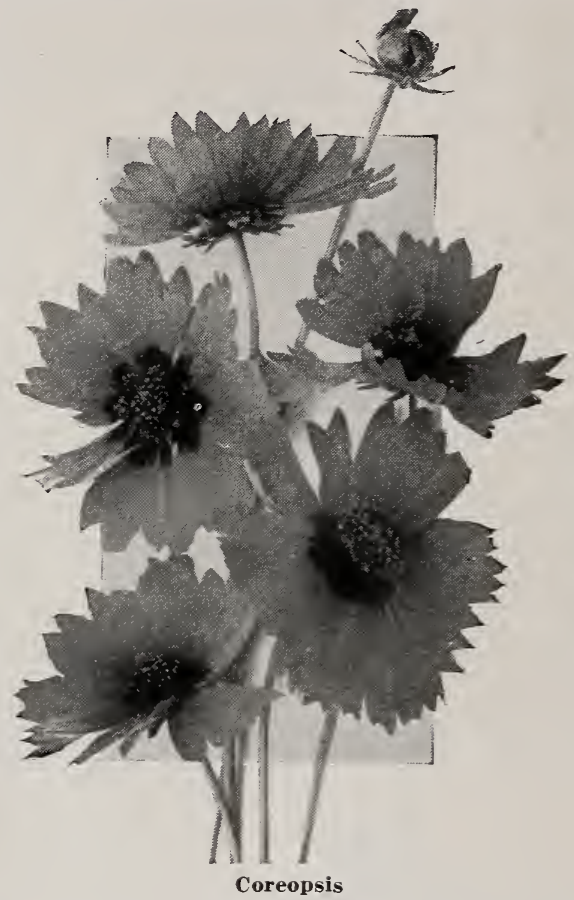

Coreopsis - A hardy, easily grown perennial, blooming all summer. The daisy like rich, golden yellow flowers on long stems, are unexcelled for cutting. 15c each; $\$ 1.50$ per 12.

Hollyhocks-One of the best hardy garden flowers for border or back ground, grow $5 \mathrm{ft}$. to $7 \mathrm{ft}$. Double, red, pink, white. $15 \mathrm{c}$ each; $\$ 1.50$ per 12 .

Pyrethrum (Painted Daisy)-A group of graceful free-flowering plants, ranging in color from white to crimson. Bloom practically all summer, but are at their best in June. $15 \mathrm{c}$ each; $\$ 1.50$ per 12.

Poppy Oriental_For gorgeous coloring, the Oriental Poppies have few rivals among hardy plants. They produce a magnificent effect in the Herbaceous border. Bloom in May and June. 3 to $4 \mathrm{ft}$. Orange with black center. 25c each.

Sweet William (Dianthus Barbatus)-The striking colors, pleasing fragrance, and freedom of bloom, make Sweet William a favorite with all lovers of hardy flowers. They are at their best in solid beds or as border for walks or drives. Grow 12 to 18 in. $15 \mathrm{c}$ each; $\$ 1.50$ per 12 . Dark Red. 
If wanted by Parcel Post add $6 \mathrm{c}$ for 1 to 5 plants; $8 \mathrm{c}$ for 6 to 10 plants; $10 \mathrm{c}$ for 10 to 12 plants. If within 300 miles of our Nursery.

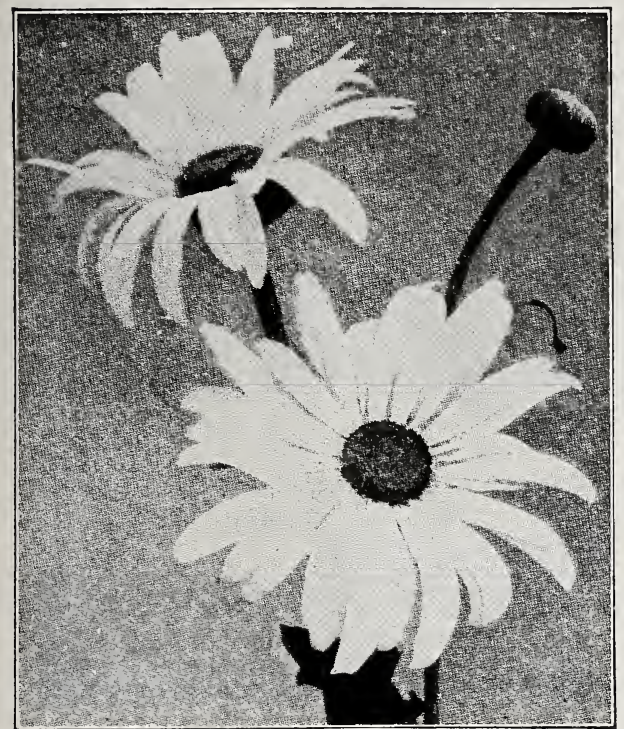

Shasta Daisy

Shasta Daisy (Alaska)-A much improved snow white with yellow daisy. Flowers large, flower. Good plants $15 \mathrm{c}$ each; $\$ 1.50$ per 12 .

Carnation Hardy - A new perennial, like in the greenhouse, only a trifle smaller. Very hardy, glowing crimson. 25c each; $\$ 2.50$ per 12 .

Veronica (Speedwell)-A two-foot border plant, with attractive foliage. Flowers are borne abundantly in July and August on compact spikes. Deep indigo blue color. 20c each; $\$ 2.00$ per 12 .
Sedum- A blooming form of live forever, in August, very showy. 25c each.

Hardy Sweet Pea frathyrus) - Showy perennial of a climbing habit. Good for the lattice covering old stumps, also good for the perennial garden. with a little staking. Continually in bloom. Fine for cutting. Colors pink or white. 25 c each; $\$ 2.50$ per 12 .

\section{Gypsophila Paniculata_- (B a bly's} Good for cutting as well as for borders. Flowers are minute but myriad, pure white, produced in immense fluffy panicles. 20c each; $\$ 2.00$ per 12 .

Statice Latifolia- (Sea L a v e n d e r). inches high, with tufts or clumps of thick, leathery foliage and immense panicles of delicate blue Forget-me-not flowers. 18 inches or more across. Will last for months as house decoration, if carefully dried. 25c each; $\$ 2.50$ per 12 .

\section{Platycodon Grandiflorum-}

(Balloon Flower). Blooms constantly from July until late in September; flowers large bell-shaped, in numerous loose racemes. 20c each; $\$ 2.00$ per 12.

Yucca Filamentosa-(Adam's Needle or Spanish Bayonet) A stately foliage and flowering plant, always conspicuous. The broad, sword-like foliage is evergreen; supporting a showy display of pendant creamy-white bells. 35c each.

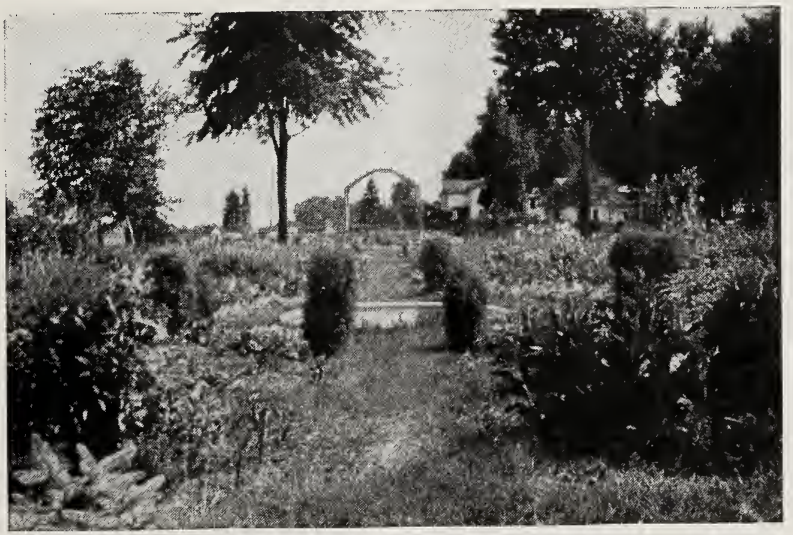

Flower Garden at Nursery. 


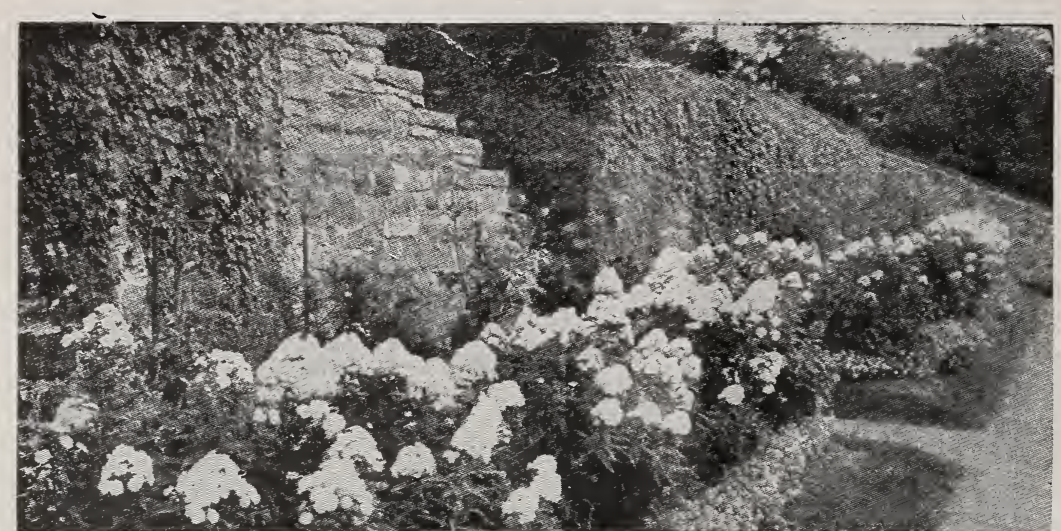

Hardy Phlox Planting

Rhinelander-One of the newer varieties, salmon pink, with claret red eye flowers and trusses large. $25 \mathrm{c}$ each; $\$ 2.50$ per 12 .

Ferdinand Cortez-Deep crimson, one of the best Red phlox. Red phlox are very scarce, and we have selected this as the best. $25 \mathrm{c}$ each; $\$ 2.50$ per 12.

Australia-This is one of the latest added to line of phloxes. It is reddish purple, or a dark wine red. Flowers are very large and extremely showy. 25c each; $\$ 2.50$ per 12 .

Miss Lingard-Pearly white flower, with a very faint pink eye, very remarkable bloomer, producing two to three crops of flowers during the season. 25c each; \$2.50 per 12 . $\$ 2.50$ per 12. each; $\$ 2.00$ per 12 . per 12. per 12.

\section{Hardy Phlox}

Beauty and usefulness bring these hardy border plants among those of greatest importance; succeeding in almost any soil or position yet they respond quickly to liberal cultivation. Their flowering season begins in July, and when the old bloom spikes are removed, extends to late fall. The varieties we offer include the most desirable kinds and cover a wide range in color. Postage-1 plant, 5c; 3 plants, $7 \mathrm{c}$; 6 plants, 9c; 12 plants, $12 \mathrm{c}$.

R. P. Struthers-Bright rosy red, with claret red eye, a very fine and popular variety. $25 \mathrm{c}$ each;

Bridesmaid-Pure white with clear carmine eye, blooms in large round heads, very attractive. 20c

Ryndstrom-Beautiful shade of rose pink, very much like the Paul Neyron rose. Flowers very large and showy, a fine variety. 25c each. $\$ 2.50$

La Vague-Lavender with light center, very best of the lavenders. 20c each; $\$ 2.00$ per 12 .

Rosenberg-Reddish violet with blood red eye, flowers very large and attractive. 25c each; $\$ 2.50$

\section{IRIS}

When you add to their extreme hardiness and ease of culture, the lavish display of blossoms, it is not surprising that they are highly prized. The charm of a bed of Iris is one of the keenest pleasures in June. Early varieties are always in bloom for Decoration Day. Later varieties prolong the blooming season.

Postage-1 plant, 5c; 3 plants, 7c; 6 plants, 9c; 12 plants, 12c.

\section{GERMAN IRIS, EARLY}

Caprice_- Rosy red, one of the newer variefeet and a good bloomer. 20c each; $\$ 2.00$ per 12 .

Dwarf Blue-The variety grows 6 to 8 inches tall, the flowers are almost a dark purple, splendid for edging flower beds or walks. $15 \mathrm{c}$ each; $\$ 1.50$ per 12 .

Gertrude-Clear blue. The flowers are borne on tall stems, 2 to $2 \frac{1}{2}$ feet tall, three to four flowers to the stem. The foliage grows 1 to $11 / 2$ feet tall. 15c each; $\$ 1.50$ per 12 .

Parsiensis-Deep purple. Grows same as above. The flowers are very large and very lasting. $15 \mathrm{c}$ each; $\$ 1.50$ per 12 .

Aurea-Canary Yellow. Bloom a little later than the two above. The flower stems are 2 to 3 feet tall. Plant a very free bloomer. $15 \mathrm{c}$ each; $\$ 1.50$ per 12.
Florentina Alba-Purple white. Flowers are very large; borne on stem 2 to $2 \mathrm{~T} / 2$ feet tall; one of the best of the white. $15 \mathrm{c}$ each; $\$ 1.50$ per 12 .

Siberian Iris-White. Blooms in June, after the German Iris are gone. Foliage is 12 to 14 inches tall; dark green and very thick; the flowers are borne on stems 2 to 3 feet tall, pure white and of medium size. $15 \mathrm{c}$ each; $\$ 1.50$ per 12 .

Japanese Iris - This variety of Iris is the blooms come the last of June and in July. They are tall growers and are of dark purple Gold and Mahogany shades. The flowers are extremely large, the largest of all Iris, many times measuring 6 to 8 inches across.

Gold Bound-White with Gold center, very fine and striking. $30 \mathrm{c}$ each; $\$ 3.00$ per 12 .

Mahogany-Beautiful mahogany color, very odd, good bloomer. 30c each; $\$ 3.00$ per 12 .

Purple and Gold-Purple petals with Gold center. This is a fine old standby variety in the Japanese. 30c each; $\$ 3.00$ per 12. 


\section{SPRING BULBS PEONIES and CANNAS}
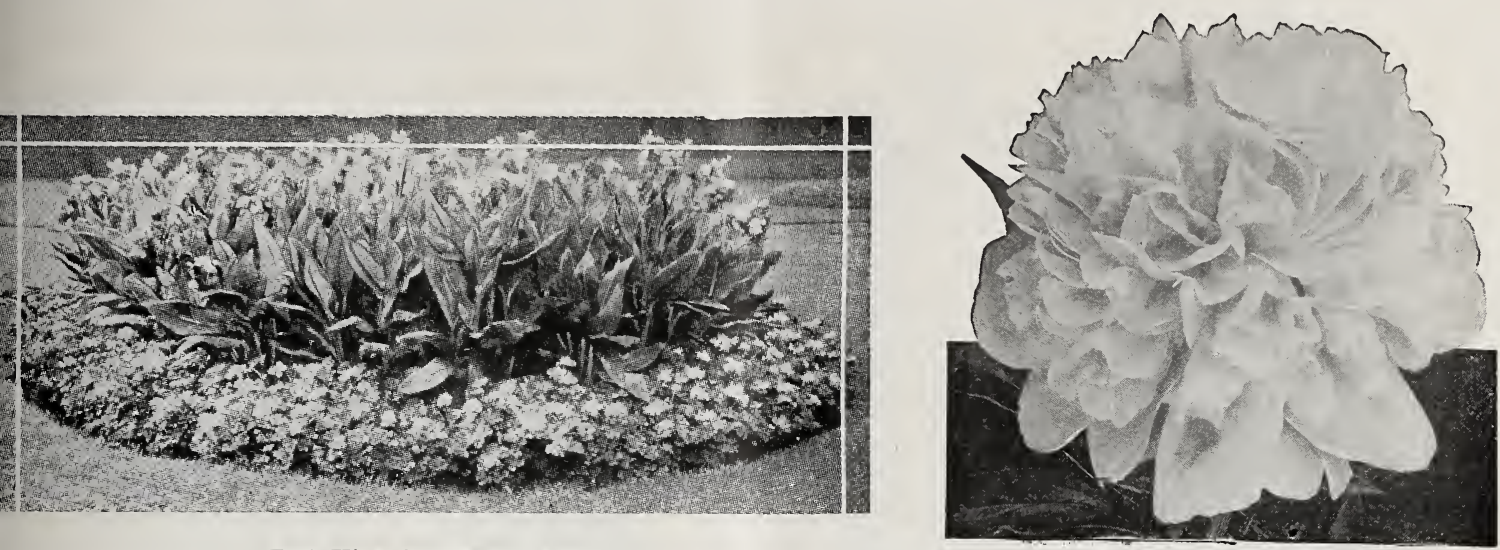

Red King Humbert Canna

Festiva Maxima Peony

\section{CANNAS}

\section{Strong Bulbs, 15c each; $\$ 1.50$ per 12}

By mail add 4c for 1 to 3 bulbs; $6 \mathrm{c}$ for 3 to 6 bulbs; 10 c for 6 to 12 bulbs.

Of rapid growth and tropical appearance throughout the summer. They present a mass of gorgeous colors. The following varieties are among the best. Good quality bulbs.

\section{Red King Humbert- $\underset{\text { leaves. }}{4}$ fr. Blowers} scarlet color, very large. The best of the bronze leaved varieties.

Eureka-3 ft. Pure white flowers; free bloomer.
Yellow King Humbert_- ${ }_{\text {very large }}^{\text {ft. }} \underset{\text { Has }}{\text { Hats }}$ yellow flowers, softly spotted with bright red. Green leaves.

Shenandoah- $3 \mathrm{r} / 2 \mathrm{ft}$. Very compact, algreen; flowers very large; color pale pink with satin sheen.

Florence Vaughn-41/2 ft. Green foliage. Flowers rich golden yellow, spotted with bright red. Extra good bloomer.

\section{PEONIES}

Strong 3 year roots.

Postage 6c on 1 plant and add 1c for each additional plant.

The most popular of hardy plants. The flowers are very large and attractive; hardy as an oak; once planted they will take care of themselves. The following list are all good, double flowering varieties:

Lucretia-Buds light pink, changing to white as flowers open; extra good grower and bloomer. $40 \mathrm{c}$ each; $\$ 4.00$ per 12 .

\section{Festiva Maxima_ Immense b1 o o m s,} delicate tinge of cream in center and pure white, small fiakes of crimson. The most popular peony grown. In great demand for cut bloom. An ideal white. 30c each.

Floral Treasure-Delicate Shell Pink; rose type; fragrant; mid-season; blooms freely. 40c each; $\$ 4.00$ per 12 .

Mrs. Cleveland- geod delicate pink, each; $\$ 4.00$ per 12 .

Delicatessima-A Dark Pink, very double; Best for Decoration Day. 50c each.

Rose Fragrant Light Red, very frag$\$ 4.00$ per 12 .
Fletcher_Delicate rose; very large and full. 40c each; $\$ 4.00$ per 12 .

Special Collection

$\left.\begin{array}{ll|}1 & \text { Fletcher } \\ 1 & \text { Festiva Marima } \\ 1 & \text { Mrs. Cleveland } \\ 1 & \text { Rose Fragrant }\end{array}\right\} \begin{gathered}\text { The } 4 \\ \text { for } \\ \mathbf{\$ 1 . 4 0}\end{gathered}$

Add 10c for Postage.

\section{Extra Fine Peonies}

Officinalis Rubra-Large, globular bloom; brilliant crimson; this is the early flowering red peony so common to the old time gardens; much used on memorial day when other peonies bloom too late. $75 \mathrm{c}$ each.

Felix Crouse-Late, large round heads perfectly double; deep crimson. marked with cardinal at base of petals. $75 \mathrm{c}$ each.

Mons. Jules Elie- This is one of varieties. Early bloomer. Pale rose in color, the flowers are extremely large, resembling chrysanthemums. $\$ 1.25$ each. 


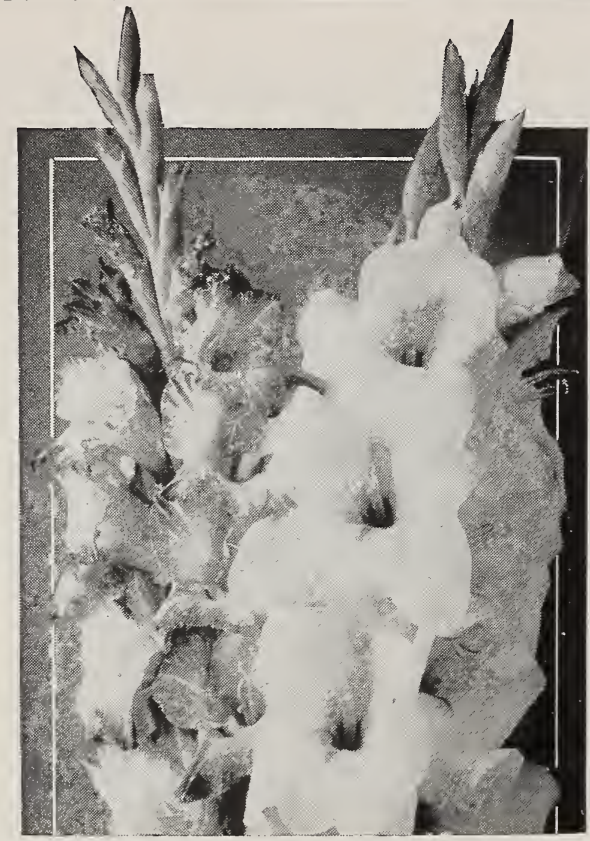

GLADIOLIS

\section{0c each. Good bulbs}

Postage $4 c$ per 1 to 3 bulbs; $6 c$ for 3 to 8 bulbs; $8 \mathrm{c}$ for 8 to 12 bulbs.

Should be planted about the first week in May. We offer some of the best varieties-strong bulbs. America-Beautiful, soft flesh-pink; faintly tinged with lavender. 12 for $40 \mathrm{c}$.

Baron Hulot-Rich, deep indigo blue. Besides being the only blue Gladiolus known, it is a really very fine sort. 12 for $75 \mathrm{c}$.

War-Considered by many the best commercial blood-red to date. Its flowers are of immense size in long spikes, and borne freely. Late. 12 for $60 \mathrm{c}$. Schwaben-One of the old favorites; pure canary yellow, shading to soft sulphur yellow; a sturdy grower. 12 for $50 \mathrm{c}$.

Mrs. Francis King-Brilliant Vermillion scarlet. A popular and effective variety for all occasions. Large size. 12 for 60 c.

Chicago White-White with lavender marking in throat. One of the earliest varieties to bloom. 12 for $50 \mathrm{c}$.

Panama-Clear pink, large flowers set well on stem. looms immense in size. 12 for $60 \mathrm{c}$.

Empress of India - Very dark velvety you will like it. 12 for $\$ 1.00$.

Mixture of named varieties, 12 for $65 \mathrm{c}$.

Standard Mixture-Good varieties mixed. Recommended to those who desire good flowers without especial reference to color effect. Good size bulbs. 50c per 12 .

\section{DAHLIAS}

Strong bulbs; 20c each; $\$ 2.00$ per 12

Postage, $4 \mathrm{c}$ for 1 to 3 bulbs; $6 \mathrm{c}$ for 3 to 8 bulbs; $8 c, 8$ to 12 bulbs. Our bulbs bloomed extra fine last fall.

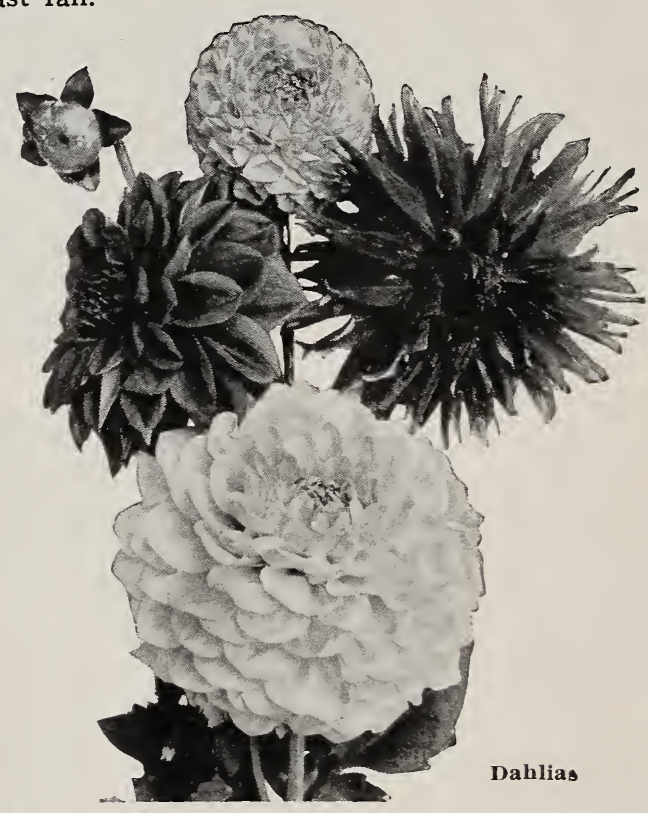

Electric (Show)-Tall growing, bright yellow, very heavy bloomer; fine variety.

Caecelia (Paeony)-Cream to white, large semidouble variety, measuring five to seven inches across.

Delice (Decorative)-A wonderful pink shade, good bloomer, flowers large.

Storm King (Show)-White, very large, fine bloomer, has a slight tinge of pink.

Zulu (Decorative)-Dark velvety red, very fine and a heavy bloomer.

\section{CACTUS DAHLIAS}

Most graceful and artistic of the Dahlias is the Cactus type, which strongly resembles the Chrysanthemum, having long, narrow, pointed florets, with the margins folded or even quilled back.

Countess of Lonsdale-Pleasing blending of salmon-pink and amber; flowers large; long and freeblooming. This is fine. 35c each.

Hogan Red-Intense coral-red, deeper at center; large flowers, with long, narrow petals. 25c each. Libelle (Cactus)-Lavender, large bloom, with pointed petals. 25c each.

\section{Grand Garden Mixture of Gladiolis}

A mixture of all the good varieties, and will give a big assortment of flowers.

TRY IT. 50 bulbs for $\$ 1.00$. Postage 10c. 


\section{ORDER SHEET}

(You will find it convenient to use this Order Sheet)

ALPHA NURSERY

Date

\section{Trees -- Fruits -- Flowers}

Ship to.

\section{Shipping Directions \\ $\square$ Express \\ $\square$ Freight \\ $\square$ Parcel Post \\ Did You Include Postage}

Post Office

Be sure to give your $\mathbf{P}$. $\mathbf{O}$.
Amt. Enclosed \$

\begin{tabular}{|c|c|c|c|c|}
\hline uantity & Varieties & Size & Price & Amoun \\
\hline & & & & \\
\hline & & & & \\
\hline & & & & \\
\hline & & & & \\
\hline & & & & \\
\hline & & & & \\
\hline & & & & \\
\hline & & & & \\
\hline & & & & \\
\hline & & & & \\
\hline & & & & \\
\hline & & & & \\
\hline & & & & \\
\hline & & & & \\
\hline & & & & \\
\hline & & & & \\
\hline & & & & \\
\hline & & & & \\
\hline & & & & \\
\hline & & & & \\
\hline & & & & \\
\hline & & & & \\
\hline & & & & \\
\hline & & & & \\
\hline & & & & \\
\hline & & & & \\
\hline & & & & \\
\hline
\end{tabular}



We will have a big assortment of summer bedding plants, blooming house plants, vines and plants for porch boxes and hanging baskets. All at rock bottom prices for the high quality stock.

For POSTAGE add $10 \%$ to the amount of the bill, in this department, within a radius of 300 miles.

\section{Plants}

Our plants are grown with lots of room and started early so that we will have big plants for our customers. Mail your orders early as we always give a little extra for early orders.

Per

Size Each Doz.

Ageratum (blue)

$2 \frac{1}{4} \quad 10 \mathrm{c} \quad \$ 1.00$

Asters (lavender) Seedlings..........

Asters (pink) Seedlings ................

Asters (white) Seedlings ............

Plumosa Fern …..........................3 $15 \quad 1.50$

Plumosa Fern ….......................... $4 \mathrm{~T} / 2 \quad 25 \quad 2.50$

Springerii Fern …........................3 3150

Springerii Fern ……..................... $4 \mathrm{~T} / 2 \quad 35 \quad 3.50$

Carnations (red ….......................21/4 $15 \quad 1.50$

Carnations (pink) …….................. 21/4 $15 \quad 1.50$

Carnations (white) ........................2/4 $15 \quad 1.50$

Begonia (Supreme) …...................4 $4 / 4 \quad 35 \quad 3.50$

Begonia (Lucerna) …....................4 $1 / 2 \quad 30 \quad 3.00$

Begonia (Lucerna) ........................6 $50 \quad 5.00$

For-get-me-not _.............................3 $10 \quad 1.00$

Heliotrope _..................................2 $1 / 4 \quad 15 \quad 1.50$

Geraniums (red) ……...................2 $21 / 4 \quad 10 \quad 1.00$

Geraniums (red) …....................... $4 \quad 20 \quad 2.00$

Geraniums (pink) .......................... $4 \quad 25 \quad 2.50$

Geraniums (white) .......................... $4 \quad 20 \quad 2.00$

Martha W. Ger............................. $4 \quad 30 \quad 3.00$

Petunias (giant double)................ 151.50

Petunias (single) ….......................2 $1 / 4 \quad 10 \quad 1.00$

Petunias (Rosy Morn) …..............21/4 $10 \quad 1.00$

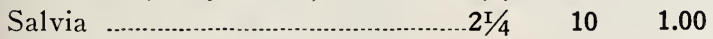

Verbenias (all colors) .................... $10 \quad 1.00$

Vinca Vines ..................................2 $1 / 4 \quad 10 \quad 1.00$

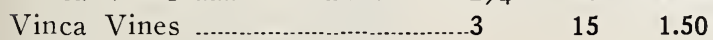

\section{Cannas}

King Hnmbert (Red)

Yellow Humbert

F. Vaughn (Yellow)

$3 \mathrm{~T} / 2$ in. pots $25 \mathrm{c}$ each; $\$ 2.50$ per 12 .

Eureka (White)

Hungaria (Pink)

\section{Pansy Plants}

Thousands of the giant flowering kinds, 25c per 12. Add 5c per 12 for postage.

\section{SPECIAL BARGAIN Coleus (Foliage Plants)}

We have one of the finest and largest assortments for miles around, and at rock bottom prices.

5 c each-50c per 12

$10 \mathrm{c}$ each-75c per 12

\section{Vegetable Plants}

Cabbage, early or late ..............................10c per 12

Tomato, Earliana …………........................ 10 per 12

Tomato, Ponderosa …...........................10 c per 12

Tomato, Stone ……...................................... per 12

Tomato, Tree ..........................................15c per 12

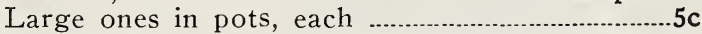

Cauliflower $20 \mathrm{c}$ per 12

Pepper, sweet ……................................... per 12

Egg Plants ............................................. per 12

Celery (self-bleaching)

$\$ 1.00$ per 100

\section{Blue Grass Seed}

\section{$\$ .45$ per $1 b$.}

Sow one pound for three square rods. This is the best lawn grass seed. Sow in April and rake in well. Postage $6 \mathrm{c}$ for $1 \mathrm{lb}$. Add $1 \mathrm{c}$ for each extra $1 b$.

\section{Garden and Flower Seeds}

We have a fine collection of the best varieties of seeds, which are listed on a separate sheet. If you did not receive the sheet, send for it.

We have lots of plants that are not listed on this page. Come to the Greenhouse and look them over. You are always welcome. During the summer we have large patches of Glads; Cannas, and Dahlias. We are always glad to show you around.

We have cut flowers and make funeral sprays, wreaths, pillows, etc. Our prices are very reasonable and our pieces are above the average in size. PHONE US YOUR ORDER.

\section{Alpha Greenhouse



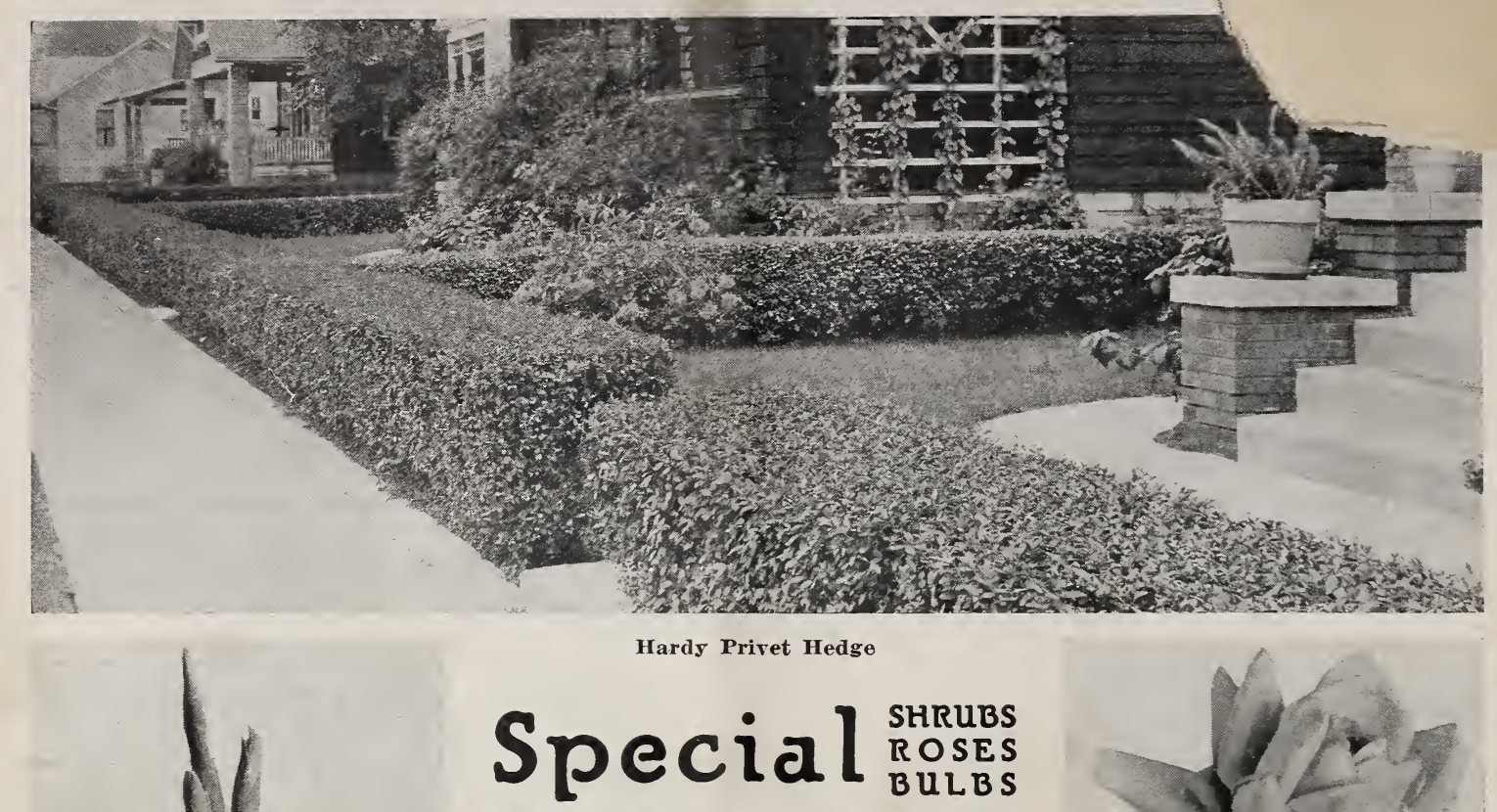

Barberry Thunbergeii-For hedges or foundo 12 in., 10 e each; $\$ 1.00$ per 12.

Spirea Van Houtei-For hedges and foundation planting. goes fine with Barberry. 12 to 18 in., 10c each; $\$ 1.00$ per 12 .

Privet Amoor River-For hedges and screens, can be trimmed to any height.

12 to 14 in., $10 \mathrm{c}$ each; $\$ 1.00$ per 12 12 to 18 in., $15 \mathrm{c}$ each; $\$ 1.50$ per 12 . Postage 10c per 12.

\section{ROSES}

35̃c each

Postage 5c each

Good roses cheap.

American Beauty Baby Rambler

Frau Karl Druschki Killarney Pink

Gen. Jacqueminot Killarney White

Soliel D Or

IIlarney Carolia Testout

La France

Gruss an Teplitz Etoile de Lyon

\section{GLADIOLIS}

GRAND GARDEN MIXTURE

A mixture of all the good varieties of glads. which will give a big assortment of howers.

$$
\begin{aligned}
& 50 \text { Bulbs for } \$ 1.00 \\
& \text { Postage 10c }
\end{aligned}
$$

\section{Alpha nursery} ALPHA, ILLINOIS

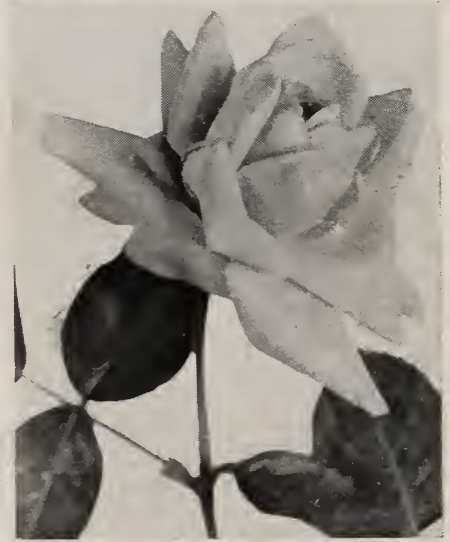

Etoile de Lyon

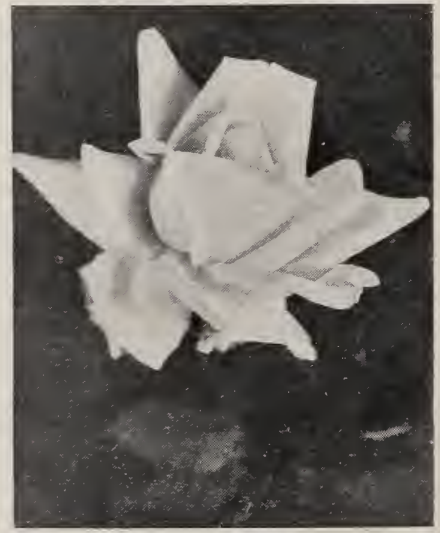

American Beauty
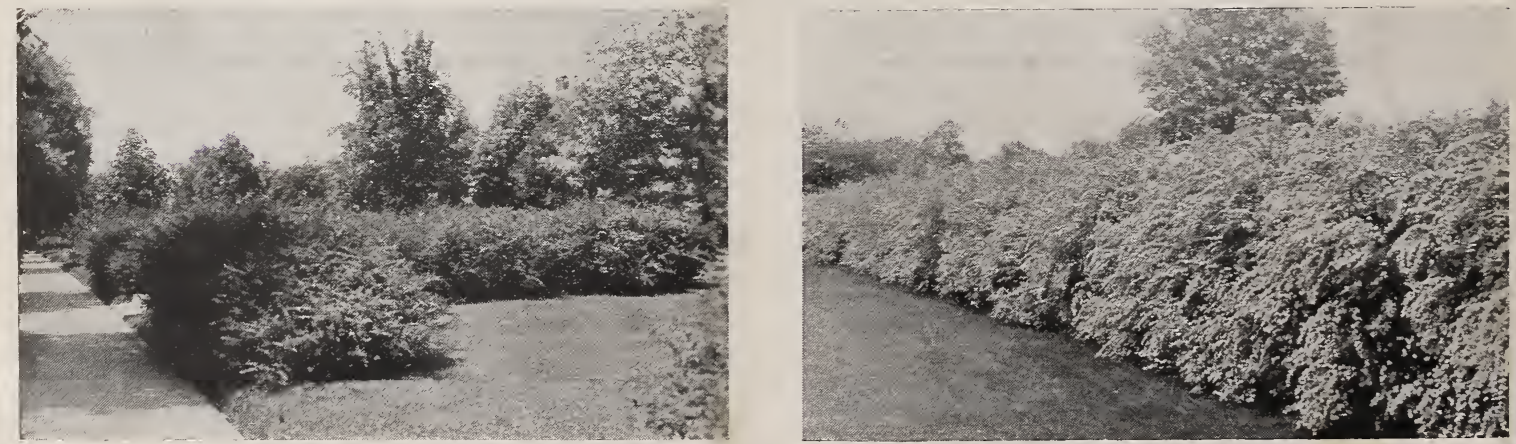